\title{
Bir Kültürel Tüketim Pratiği Olarak Netflix Dizileri
} (Araştırma Makalesi)

\author{
Netflix Series as a Cultural Consumption Practice \\ Doi: 10.29023/alanyaakademik. 821572
}

\section{Y. Derya BİRİNCİOĞLU}

Doç. Dr., İstanbul Gelişim Üniversitesi, UBYO,

deryabirincioglu@gmail.com

Orcid No:0000-0003-0119-9341

\section{Ŭ̆ur BALOĞLU}

Dr. Öğr. Üyesi, İstanbul Gelişim Üniversitesi, UBYO,

ugurbaloglu@gmail.com

Orcid No: 0000-0002-7716-3663

Bu makaleye atıfta bulunmak için: Birincioğlu, Y. D. \& Baloğlu, U. (2021). "Bir Kültürel Tüketim Pratiği Olarak Netflix Dizileri”, Alanya Akademik Bakış, 5(2), Sayfa No.547-570.

\section{Anahtar kelimeler: \\ Yeni İleme Pratikleri, Kültürel Tüketim, Boş Zaman, Yaşam Tarzl, Netflix Etkisi, Illetişim Araştırmaları.}

Makale Geliş Tarihi: 04.11.2020

Kabul Tarihi: 05.04.2021

\section{ÖZET}

21. yüzyılda medya içeriklerinin kullanımına yönelik bireysel tüketimler radikal değişimler gösterirken aynı zamanda izleme pratikleri de gelenekselden dijitale dönüşmekte ve aşırı izleme motivasyonları belirginlik kazanmaktadır. Özellikle dizi içeriklerinin tüketilmesinde gözlemlenen bu değişiklik toplumsal grupların belirlediği sosyal statü göstergesine dönüşmekte ve orta sınıfin boş zaman pratiklerinde önemli bir yer haline gelmektedir. Netflix'in son bir yıl içindeki üye saylsında yaşanan dramatik artış da bu sosyal statü olgusunu desteklemektedir. Bu noktada yapılan bu çalışmadaki temel amaç; bir orta sınıf tanımlaması yapmak değil, özellikle dijital teknolojilerin yaygınlaşması ile birlikte bir orta sınıf boş zaman etkinliği olarak televizyon izleme pratiğinde meydana gelen değiş̧imi tüketim ve yaşam tarzı bağlamlarında değerlendirmektir. Çalışmanın çıkış noktasını Weber'in sosyal statü ve Bourdieu'nun sinıf habitusu kavramları çerçevesinde sosyal sinıfların tüketim alışkanlıklarında alt sinıfların üst sinıfları taklit ederek kendilerini farklı sunma çabalarına benzer şekilde ortaya çıkan değişimi görünür kılmak düşüncesi oluşturmaktadır. Bu bağlamda çalışmada günümüzde, sosyal grupların boş zaman etkinliğini dijital medya platformları aracılığtyla deneyimleyip geleneksel medyada üretilen programlardan farklılaşmaya çalışıp çalışmadığının ve boş zaman etkinliğini dijital medya platformu üzerinden üretme süreçlerinin bulgulanması amaçlanmaktadır. Bu verilere ulaşılması amacıyla, çalışmada 12 (on iki) kişi ile derinlemesine mülakat yöntemiyle görüşme yapılmıştır. Katılımcıların sosyal statü sıralamasında alt statü grubunda kendilerini konumlandırma endişelerinin yoğunluğu nedeniyle geleneksel medya tüketimini olumsuzladıklart ve kendilerini kültürel sermaye boyutunda daha nitelikli gördükleri üst sınıfa ait olarak değerlendirdikleri sonucuna ulaşılmıştır. 
Keywords:

New Television

Viewership, Cultural

Consumption, Leisure

Time, Life-Style,

Netflix Effect,

Communication

Research.

\begin{abstract}
In the 21st century, while individual media consumption shows radical changes, at the same time, watching practices are transforming from traditional to digital and over-watching motivations are also becoming evident. This change, especially observed in the consumption of TV series content, turns into a social status sign determined by social groups and becomes a notable place in the leisure practices of the middle class. The dramatic increase in Netflix's number of members in the last year also supports this social status phenomenon. In this context, the main purpose of this study is; not to make a middle-class definition, but to evaluate the change in television watching practice in terms of consumption and lifestyle as a middle-class leisure activity especially with the spread of digital technologies. The starting point of the research is the idea of making visible the change in the consumption habits of the social classes, similar to the efforts of the lowerclasses to present themselves differently by imitating the upper-classes within the framework of the concepts of Weber's social status and Bourdieu's class habitus. In this context, it is aimed to find out whether social groups are trying to differentiate from the programs produced in traditional media by experiencing their leisure activities through digital media platforms, and the processes of producing leisure activities through the digital media platform. In order to collect these data, in-depth interviews were conducted with 12 (twelve) people in the research. It was concluded that the participants negated traditional media consumption due to the intensity of their concerns about positioning themselves in the lower status group in the social status ranking and they evaluated themselves as belonging to the class they consider more qualified in terms of cultural capital.
\end{abstract}

\section{GíRIŞ}

Günümüzde kültürel çalışmalar alanının en önemli isimlerinden biri olan Bourdieu'nun çalışmalarını iletişim araştırmaları çerçevesinde yeniden okumak değişen sosyal ve kültürel yaşamı anlamak açısından yol göstericidir. Temelde Marks ve Weber'in eleştirel görüşlerinden yararlanan ancak bunu doktiriner olmayan bir yoldan yapan Bourdieu, toplumsal eşitsizlik sistemlerinin kültürel pratiklerle ilişkisini ortaya koymaya çalışır (Smith, 2007, s.185; Hitchcock, 2008, s.148). Reel toplumsal yaşamda iktidar söylemini yeniden üreten ve toplumsal eşitsizlikleri belirleyen sermaye türlerini ekonomik, toplumsal ve kültürel çerçevede ayrımlayan Bourdieu, kültürel sermayenin ekonomik ve toplumsal sermaye bağlamında belirlendiğini savunur.

Bourdieu'nun yaşam tarzları ve kültürel beğeni düzeyi arasındaki ilişkiyi kültürel sermaye olarak teorize ettiği Ayrım'ın 1979 yılında Fransa'da yayımlanmasından sonra iletişim çalışmalarına da katkısı olmuştur. Toplumsal yaşam alanında farklı grupların kültürel tüketim pratiklerindeki ve beğeni düzeylerindeki farklılıkları alt, orta ve üst sınıfsal yapı çerçevesinde ayrımlayan çalışma, yaşam tarzlarındaki farklılıkları sınıf habitusu içinde değerlendirir. Bourdieu'ya göre habitus, farklı sınıfa ait bireylerin kültürel tüketim pratiklerini üreten ve aynı zamanda onları sınıflayan bir kavramdır. Öyle ki, sembolik çatışmanın alanı olarak betimlenen kültür, farklı beğeni düzeyleri için ürünlerin üretimi ile o ürünlerin tüketimi arasındaki ilişkide oluşur (Bourdieu, 2015, s.254). Özellikle siyasal ve ekonomik alanda tek kutuplu dünyaya 
doğru ilerleyen bir süreçte -Marksist düşüncenin ve sosyalist yönetim biçiminin zayıfladığı bir dönemde- Bourdieu'nun sınıf analizi çerçevesinde kültürel çalışmalarını anlamak önemlidir. Nitekim Bourdieu, ortodoks Marksist geleneği aşarak toplumsal kategorizasyonu kültürel, dini ve/veya eğitim gibi daha nitel özelliklerle belirleyerek toplumsal konumların farklılaştığını gösterir (Garnham, 1993, s.187). Bu bağlamda Marks'1n sermaye kavramı genişleyerek salt ekonomik alanda değil toplumsal, kültürel ve sembolik alanlara yayılır. Böylece sınıfsal konumu belirleyen parametrelerin birbiri ile ilişkisiyle toplum, birbirinden görünmez çizgilerle ayrımlanan görece özerk alanların oluşturduğu grupların var olduğu bir uzam olarak resmedilir. $\mathrm{Bu}$ noktada kültürel sermayeyi belirleyen habitusun arasındaki derinlikli ilişki daha net anlaşılabilir. Bireylerin içinde bulundukları ya da içine doğdukları sosyal alan bireyin pratiklerini etkileyerek o alanın özelliklerini yansıtır. Başka bir deyişle, kültürel pratikler, bireyin içselleştirilmiş eğilimleri çerçevesinde ortaya çıkar. $\mathrm{Bu}$ bağlamda bireyin deneyimlediği kültürel pratikleri ile kültürel beğeni düzeyi arasında anlamlı bir ilişki mevcuttur. Özellikle dijital platformların yaygınlaşması sonrası değişen izleme pratikleri de toplumsal beğeniler çerçevesinde geleneksel ve modern ayrımını inceleme firsatı sunar.

Medya kullanımına yönelik bireysel motivasyonların artış gösterdiği günümüzde izleyicilerin farklı nedenlerle dijital platformlara yönelmesi üye sayılarında niceliksel bir artışın yaşandığını göstermektedir. 2019 yılının son ayında Netflix, Türkiye'deki tekil üye sayısını 1.5 milyon olarak açıkladı. 2019 Şubat ayında 65 bin olan abone sayısının giderek artması boş zaman etkinliği olan televizyon izleme pratiğinin dijital platfomlara kayma nedenini araştırmayı değerli kılmaktadır. Hâkim kültürel yapıyı denetleyen orta sınıfın tüketim/boş zaman olgusunu popüler kültür ürünleri üzerinden inşa etmesi, toplumsal dinamiğin işlemesinde ve izleyiciliğin dönüşümünde oldukça etkili bir role sahiptir. Zira küresel bir sermaye olarak Netflix'in Türkiye'deki sermayesini artırması ile kültürel beğeniler arasında anlamlı bir ilişki kurulduğuna yönelik veriler bu araştırmanın temel savını oluşturur. Aylık ödeme yapılarak abone olunan sistemin genellikle (yeni) orta sınıfa yönelik ürünler sunması, günümüzde giderek genişleyen buna karşın ekonomik olarak daralan orta sınıfın 'maddi eksende' kaybettiği statüyü kültürel düzeyde farklılaşarak tüketimi araçsallaştırmasına neden olduğu bulgulanmaktadır. Başka bir deyişle orta sınıfın sermaye gelişmelerine paralel olarak ekonomik konumlanmasının yeniden tanımlanması ister istemez bu sınıfın yaşam tarzlarının, boş zamanının ve kültürel kimliğinin de yeniden inşa edilmesini sağlar. Küresel kapitalist söylemde Bourdieucu bakışla yaşam tarzları bireylerin kendi benliklerini sosyal/özel ortamdaki tüketim alışkanlıkları ile nasıl inşa ettikleri üzerinden tanımlanabilir. Bu anlamda yaşam tarzı özellikle orta sınıf bireyler için ayrıca bir önemdedir çünkü Weber'e göre bireyler sınıfsal yapının kültürel boyutunda yukarı eksene doğru hareket ettiğinde prestij ve saygınlık kazanır. Zira sosyal statü grupları, ekonomik sınıfsal konuma dayanabilir ancak salt tek başına yeterli değildir. Yaşam tarzı, eğitim, mesleki saygınlık gibi farklı özelliklerin belirlediği statü, birbirinden farklı ekonomik sınıftaki bireylerin yetiştirilme tarzı, eğitim seviyesi gibi farklı noktalar üzerinden eşitlenebilir (Weber, 2012, s.423). Bu noktada statü farklılıkları ve yaşam tarzı arasında kurulan ilişki bireyin tüketim pratikleri çerçevesinde belirlenir. Seçkin (üst) sınıfın (kültürel) otoritesi ile kültürel değerler dizgesinin birbirine bağlı olduğu toplumsal yapılar ortak bir yaşam tarzı ve toplumsal saygınlık düzeyi etrafında ayrımlanır. Toplumda yazılı olmayan ve görünmez çizgilerle ayrımlanmış bu gruplar yetiştikleri ortam ve aldıkları eğitimler çerçevesinde benzer yaşam tarzı kurgular. Bu bağlamda Weber'in statü kavramı ile Bourdieu'nun kültürel sermaye kavramı arasında kurulacak ilişki, günümüzde değişen kültürel pratiklerin nedenselliklerini anlamaya yardımcı olabilir. 


\section{SOSYAL STATÜ, HABITUS VE TÜKETIM ALIŞKANLIKLARI}

Modern dünyanın kavramlarından biri olan yaşam tarzı, farklı toplumsal statüdeki kişilerin tüketim faaliyetlerini referans alır. Yaşam tarzı kavramına Marksist perspektiften yaklaşıldığında bireyin ekonomik durumuna göre belirlenen, davranış, kanaat, tutum, değer ve yaşam pratiklerini şekillendiren bir olgu olduğu söylenebilir (Sobel, 1981, s.7). Buna göre aynı ekonomik sınıftaki bireyler benzer yaşam biçimleri geliştirebilir. Marks'in ekonomik temelli yaklaşımına, Weber, toplumsal ve siyasal düzeydeki ilişkileri de eklemleyerek toplumsal tabakalaşma çerçevesinde sınıfsal farklılıkları yorumlar. Toplumsal tabakalaşma, bireyin tüketim alışkanlıkları, yaşam tarzı ve sosyal statü gibi farklı niteliksel özellikler bağlamında ayrımlanır (Eyce, 1999, s.278, 279). Toplumsal sınıflar, benzer gündelik yaşam pratiklerine sahip ve/veya yaşam tarzları sayesinde belirli mal ve hizmetlere ulaşabilen insanlardan oluşur (Turner, et al. 2010, s.230). Weberyen modelde, insanlar sosyal organizasyon içinde ilişkilerini yaşam tarzlarına ilişkin semboller bağlamında tüketim alışkanlıklarına yansıtır. Böylece tüketim nesnesi dolayımıyla bireyin kendini konumlandırması sağlanır. Bu konumlandırma zaman içinde alt statüdeki insanlar tarafından taklit edilerek değerini kaybedebilir. $\mathrm{Bu}$ bağlamda Weber'e göre (2012, s.423), toplumsal sınıflar, aşağıdan yukarıya doğru sürekli bir taklit mekanizmasıyla hareket eder. Buradaki temel nokta Weber'in toplumsal sınıf ve tüketim arasındaki ilişkiyi statü kavramıyla yorumlamasıdır. Öyle ki, sosyal statü, Weber'e göre, belirli yaşam tarzlarını gösteren tüketim pratikleriyle tanımlanır (2012, s.303). Marks'ın ekonomik sınıf gibi objektif bakış açısı ile Weber'in sosyal statü ve saygınlık gibi sübjektif perspektifini birleştirmeye çalışan Bourdieu'ye göre ise benzer yaşam tarzına sahip insanlar, gündelik yaşamdaki pratiklerinin içinde bulundukları toplumsal çevre ile karşılıklı ilişki kurarak bir alan yaratır (Palabıyık, 2011, s.126). Yaratılan alan kültürel beğenilerin farklı pratiklerde benzer yaşam tarzlarını ortaya çıkarır. Başka bir deyişle, "beğenilerin farklı pratikler bağlamındaki cisimleşmesi müşterek sınıf-eksenli kültürel kalıpların oluşmasına sebebiyet verir ki, bunun sonucu "türdeş yaşam tarzları"dır" (Bourdieu, 2015, s.16). Bu bağlamda Bourdieu'ya göre toplumda sınıflar kendi habituslarını oluşturur. Geçmişten bugüne ekonomik, siyasal ve/veya diğer yapılarla toplumsalın değişimi süreğen bir süreçte gerçekleşir. Habitus bu süreçte bireylerin değişen dünyanın nesnel algısını kuran uzamı niteler (Palabıyık, 2011, s.130).

Günümüzde tüketim alışkanlıklarını sosyal statü tartışmalarından ayrı düşünmemek gerekir. Özellikle orta sınıf tartışmaları, neoliberal politikaların kültürel tüketim ile ilişkisi çerçevesinde değişen yaşam biçimleri üzerinden yorumlanırsa günümüzde salt ekonomik anlamda değil kültürel olarak da değişim daha net görülebilir. Ulusaşırı şirketlerin piyasayı domine etmesiyle "yeni orta sınıf" olarak tanımlanan toplumsal sınıfın zenginleşmesi tüketim alışkanlarının değişmesi için itici bir güç olur (Özonur, 2010, s.196). Bu bağlamda tüketim nesnesini hayatın merkezine konumlayan yeni orta sınıfın rasyonel bir bakışla kendisini diğer alt sosyal sınıflardan farklı bir noktada konumlama çabası tüketim ve sosyal statü arasındaki karşılıklı ilişkiyi görünür kılar. Böylece farklı tüketim pratikleri geliştirerek yaşam tarzını üst-konumsal bir noktaya taşımaya çalışan birey, benzer sosyoekonomik statüdeki insanlar ile aynı eğilimleri sergiler. Her ne kadar tüketim, meta-nesne (tüketim eşyası) üzerinden yorumlanan bir kavram olsa da günümüzde tüketim endüstrisinin ilgisi giderek bireyin (boş) zamanına yönelmektedir.

\footnotetext{
${ }^{1}$ Yeni orta sınıf terimi, kapitalist ekonomik sistemin özellikle 1980'li yıllardan sonra bağımsız bir şekilde çalışan insanların sayıca azaldığını ve geleneksel orta sınıf tanımının ortadan kalktığını iddia eder. Buna göre, beden işçisi olmayan ancak yine de bir sermaye sahibine bağımlı olarak çalışan yüksek gelir ve statüye sahip kişilerin olduğu grubu tanımlar (Ross, 1978; Wynne, 2002). 
Post-endüstriyel yaşam tarzında gerçekleşen kültürel dönüşüm beraberinde kapitalist ekonomik sermayenin çıkarına işler bir form kazanır.

Bourdieucu habitus kavramı çerçevesinde yeni orta sınıfın yaşam biçimleri günümüz tüketim pratikleri üzerinden incelendiğinde sınıfsal ayrışma çabası daha net gözlemlenebilir. Özellikle kültürel sermayesi ile alt sınıflardan ayrışır ve tüketim pratikleriyle üst sınıfa yaklaşmaya çabalar. Yeni tüketim pratikleri, insanların kendi kimliklerini belirli semboller aracılığıyla inşa etmelerine, kim olduklarını ve/veya kendilerini toplumsal organizasyonda nasıl görünmek istediklerine yardımcı olur. Buradaki önemli nokta, tüketimin demokratikleşmesi sonrası mal ve hizmet tüketimindeki artışın geçmişteki gibi sosyal sınıf ayrımını muğlaklaştırmasıdır. Başka bir deyişle, belirli bir mekânda yeme-içme pratiği gerçekleştirmek, bir telefona sahip olmak ya da bir arabayı kullanmak, bireyi doğrudan üst sınıfsal konuma yerleştirmeyerek onun sosyal statüsünü de yansıtmaz. Ancak bu tür tüketim pratikleri bireyin kim olmaktan ziyade kim olmak istediği konusunda fikir verir (Sweetman, 2003, s.529). Bu bağlamda insanlar, belirli bir sosyal sınıfın içinde olmaktan çok o sosyal sınıfi/kimliği arzu ederek yeni tüketim pratiklerini geliştirirler. Tüketim alışkanlıklarının sınıf kavramından giderek ayrılarak arzu edilen statü grubuna dair bir kimlik geliştirme amacı taşıdığı söylenebilir (Bocock, 2005, s.74). Kimliğin belirli bir yaşam tarzı çerçevesinde geliştirilmesi yeni tip tüketicinin bireyselciliğine de vurgu yapar. Günümüzde bireyselciliğe önem veren tüketiciler (Slater, 1997), ulusaşırı şirketlerin tüketimi evrenselleştirmesiyle hem standart beğeni düzeyinde kalırlar hem de aşırı meta tüketimi ile farklılaşmaya çalışırlar. Özellikle tüketimin kişiselleştirilmesi olgusu izleme pratikleri çerçevesinde incelendiğinde yeni medya tüketim pratiklerinin geleneksel izleme eğilimlerinden farklılaşma çabası olarak okunabilir.

\section{TELEVIZYONUN DÖNÜŞEN YAPISI: DİJITAL PLATFORMLAR VE YENI İZLEME PRATIKLERİ}

Televizyon yayınının başladığı tarihten itibaren yapılan tüm tartışmaların içerisinde televizyon ve izleyici kavramlarının birlikte yer aldığı söylenebilir. Bu sebeple televizyon yayıncılığına dair yapılan çalışmaları değerlendirirken izleyicinin yeri merkezi bir öneme sahiptir. İzleyici televizyonun değişen yapısında farklı konumlandırma durumlarına tabi olmaktadır. Buna göre televizyon ve izleyici ilişkisi değerlendirildiğinde ortaya çıktığı andan itibaren tek taraflı bir yap1 özelliği gösterdiği görülmektedir. Medya metinlerinin oluşturduğu yayın içeriğine yönelik izleyicinin herhangi bir etkisinin ve katılımının gerçekleşmediği bu durumda izleyiciler pasif olarak konumlandırılmaktadır. Gündelik hayatın monotonluğuna renk katmak, dinlenmek, hoş vakit geçirmek ve boş zamanı değerlendirmek için izlenen televizyon, Katz'ın (1959) kullanımlar doyumlar yaklaşımı çerçevesinde izleyicinin aktif olarak konumlandırılmasını sağlar. Televizyon izleyicinin yayınlanan içerik içerisinden istediği medya metnini seçebildiği ve istediği kadar tüketebildiği bir şekle dönüşür. Televiyon izleyicinin yayınlanan içerik içerisinden istediğini medya metnini seçebildiği ve istediği kadar tüketebildiği bir şekle dönüşür.

Televizyon ve izleyici arasındaki en temel değişimin iletişim ve internet teknolojilerindeki gelişimler ile birlikte yaşandığı söylenebilir (Uluç, 2008, s.116). Özellikle yeni medyanın etkileşimsellik özelliği ile birleştirilen medya metinleri aracılığıyla izleyiciler belirlenen rolü üstlenerek aktif olarak konumlandırılmaktadır. Televizyon izleme pratiğinin toplumsal niteliği iletişim teknolojilerinin izlerkitleyi aktif olarak konumlandırması ile birlikte ilk olarak bireysel bir niteliğe ikinci olarak ise kültürel sermaye bağlamında statüsel bir niteliğe dönüştürür. 
2010'lu yılların başlarında Youtube sitesinden ulusal ve uluslararası kanalların tekrar yayınlarının verilmesi de televizyon yayınlarının internet ortamına taşınmasında ve izleme pratiğinde bir kırılmanın yaşanmasında etkili olmaktadır (Sar1 ve Türker, 2021, s.61). İnternet üzerinden dağıtılan televizyon hizmetinin Youtube aracılığıyla büyümesi ve kitleselleşmesi video tüketimini dönüştürerek izleyicinin izledikleri şeyler üzerindeki kontrol düzeyini artırır. İnternetin yaygınlaşması ve OTT platformlarının artış göstermesi ile birlikte izleyicilerin tüketim pratiklerinde değişiklikler meydana gelir. Başka bir deyişle televizyonun internet ile etkileşimini sağlayan dijital platform kavramı karşımıza çıkmaktadır. İzleyiciler tarafından geleneksel televizyon yayıncılığına yüklenen negatif anlamlar dijital platform aracılığıyla yeniden üretilen televizyonlarda daha uzun süre zaman geçirilen yeni bir izleme pratiğini yaygınlaştırmaktadır. Başta Netflix olmak üzere Hulu, Amazon Prime, Blu Tv, Puhu Tv, Gain, Mubi ve Exxen gibi internet üzerinden yayın yapan televizyon platformları kullanıcılarının izledikleri içeriği bitirdikten sonra yeni bölüme geçmelerine dair yaklaşımlar sergilemekte ve arşivlerine yaptıkları eklemeler ile izleyicinin bir oturuşta birden çok içerik izlemesini teşvik etmektedir.

Dünya ve Türkiye pazarında oldukça yüksek kullanıcı sayısına sahip olan Netflix, serileştirilen medya metinlerini izleyici ile buluşturarak izleyici dönüşümlerinin de farklılaşmasına neden olmuştur. Bernard Jaworski, Netflix'in kurulduğu andan itibaren küresel prodüksiyon platformu olmaya yönelik bir öngörüye sahip olduğunu ifade etmektedir. Jaworski'ye göre 1990'ların sonlarında teknolojik dönüşümü ticari hizmetlere aktarabilen firmalardan biri Netflix'tir. İnternetin ya da netin ticari bir güç olarak yeni yeni değerlendirilmeye başlandığı bir süreçte posta yoluyla DVD kiralama sistemlerini kullanıcıları ile paylaşan bu platform, Netflix adını alarak orijinal içerik, akış ve küresel prodüksiyon platformu olacağına yönelik öngörüsünü adı ile ortaya koymuştur (Jaworski, 2021). 1997 yılında Reed Hasting ve Marc Randolph tarafından internet üzerinden film kiralama hizmeti amacıyla kurulan bu platform, 2007 yılı itibariyle kendi tarafından üretilen film ve dizi içeriği oluşturmaya başlar (Blair vd., 2019, s.4). 2013 yılında ilk orijinal içeriğini ürettiği House of Cards dizisinin 13 bölümlük ilk sezonunu aynı anda yayınlayarak geleneksel yayıncılık ilkelerinde kırılma yaşanmasını sağlar (Akkuş, 2019, s.179). 2016 yılı ile birlikte ise tüm dünyada popüler bir nitelik kazanan dijital platform olma özelliği kazanır. OTT platformları arasında Netflix'in küresel pazarda belirgin bir şekilde yükselmesinin nedenleri arasında sadece öngörü içeren platform adı olduğu söylenemez. Aynı zamanda bireyselleşmeye ve mobilleşmeye uygun bir tasarımı kullanıcılarına sunması da etkilidir. Kullanıcılar tek bir hesaba üye olarak kendilerine ait birden çok profil oluşturabilmekte, televizyon, bilgisayar, tablet ve cep telefonu gibi birbirinden farklı mecralardan ulaşım sağlamakta ve bu profillerden kendi beğeni yapılarına uygun içeriklere yapay zekâ algoritmaları sayesinde ulaşabilmektedir. Bu izleme pratiğindeki değişim izlerkitlenin/kullanıcının içeriklere ulaşımının kendi kontrolü altında olduğu düşüncesi yaratırken kendisinin belirlemediği bir havuzdan seçim yaptığı gerçeğini görmesine de engel olmaktadır.

Platformlar aracılığıyla yaygınlaşan yeni dijital yayıncılık anlayışı; reklam arası içermeyen, daha kısa süreli ve bir nevi ekonomik tek bölümlü anlatılar Türk seyircisinin de dikkatini çeker. Televizyon dünyasının bir diziye ilgi uyandırmak için haftalık uzatma ya da boş sahne uygulamalarını ortadan kaldıran bu akış, izleyicinin birden fazla bölümü duraklama olmaksızın tüketebilir hale gelmesini sağlar. Böylelikle izleyici haftalık ya da parça parça ulaştığı içeriği tüketmek/izlemek yerine programın tüm sezonlarının bir kerede yayınlanması ile tek oturuşta "aşırı izleme/kesintisiz izleme" (binge-watching) pratiği edinir. Aşırı izleme/kesintisiz izleme 
pratiğine yönelik standart bir tanımlama bulunmamakla birlikte bu pratiği ifade etmek için serileştirilen bir programın/dizinin birden çok bölümünün ardışık olarak kendi belirlediği zaman dilimde ve hızda tüketmek ya da bir programın/dizinin iki ila altı bölümünün bir oturuşta izlemek şeklinde tanımlamalar yapılmaktadır (Spangler 2013; Analect, 2014). Aşırı izlemenin/ kesintisiz izlemenin gerçekleşmesi için serileştirilen içerik üretimlerine ulaşmak gereklidir. Bu izleme pratiğinin yaygınlık kazanmasında internet televizyon platformları ve SVOD servis sağlayıcıları dışında yer alan internetteki dizi sitelerinde de video oynatıcıların hemen üstünde veya altında yer alan "sonraki bölüm" butonu ile takip eden bölüme geçişin etkili olduğu ifade edilmektedir (Tryon, 2015, s.107). Netflix'in internetteki dizi sitelerinin uygulamalarını referans alan stratejisi aşırı izleme pratiğinin kullanıcılar tarafindan benimsenmesinde etkili olmaktadır. Hatta 13 bölümlük sezon yayınlarını izleyiciye sunan ve izler kitleyi bu içeriği izlemek için teşvik eden politikaları ile aşırı izleme pratiğinin yaygınlaşması Netflix etkisi olarak isimlendirilmektedir (Jenner, 2018). Deloitte'un Amerika Birleşik Devletleri'nde yapmış olduğu araştırmaya göre Amerikalar'ın yüzde 70'i zaman geçirme aracı olarak aşır1/kesintisiz izlemeyi tercih etmektedir (Steiner ve Xu, 2020). Benzer bir çalışma Webrazzi Insights'ın içerik izleme ve dinleme alışkanlıklarına dair ocak ayında Türkiye'de de yapılmıştır. Medya Tüketim Alışkanlığı raporunun sonuçlarına bakıldığında Netflix etkisinin hala yoğun bir şeklide devam ettiği OTT hizmeti veren platformlar arasında yüzde 68.3 ile Netflix'in tüketim alanında başı çektiği, yüzde 18 ile ikinci beIN Connect ve üçüncü GAIN, yüzde 16.9 ile dördüncü sırada ise YouTube, yüzde 16.3 ile beşinci sırada ise Blutv'nin yer aldığı görülmektedir (Türdü, 2021).

Son yıllarda giderek artan dijital platformlar aracılığıyla tüketim odaklı toplumun (Baudrillard, 2016) alışkanlıklarının da değiştirdiği söylenebilir. Genellikle ev, sosyal ortamlar ve/veya kamusal alanlar gibi kolektif bir paylaşım sürecini niteleyen boş zaman olgusu yeni iletişim araçlarının yaygınlaşması ile değişmeye başlamıştır. Bu durum gündelik yaşam pratiklerinde değişme, boş zaman aktivitelerini organize etme, iletişim kurma ve/veya sosyalleşme biçimlerini de etkiler (Viñals-Blanco, 2015, s.171, 172). Öyle ki, yeni iletişim teknolojileri işiçi zamanda boş zaman aktivitelerini; iş-dışı zamanda da iş-içi aktivitelerini gerçekleştirebilme imkânı sağlayabilir. Başka bir deyişle birey yeni iletişim teknolojilerini iş-içi zamanda Insatgrama girerek, tweet atarak, takip ettiği bir diziyi izleyerek kullanabileceği gibi iş-dış1 zamanda whatsapp'tan gelen bir mesajla, rapor yetiştirmek durumunda kalıp hazırladığı raporu yine bu uygulama üzerinden paylaşabilir. Bu bağlamda bireyin tüketim aktivitesi salt iş-dış1 boş zamanlarında uyguladığı bir pratikten ziyade yaşamın her alanını kapsayan daha geniş bir zaman dilimine yayılır (Sintas, de Francisco \& Álvarez, 2015, s. 83). Böylece yeni kültürel ve sosyal iletişim biçimleri ortaya çıkarak boş zamanda 'ev', bireyin merkezde konumlandığ bir alan olur. Zira dijital platformlar ve yeni iletişim teknolojileri, bireyin hem sosyalleşebildiği hem de kültürel aktivitelerini yapabildiği bir ortam yaratır (Şaylan, 2002, s.153). Bu ortam bireyin boş zamanını metalaştırıp kitlesel olarak üretilmiş ürünlerin tüketilmesini sağlarken; kişiselleştirilen tüketim ürünleri vasıtasıyla bireylere biricik olma vaadi de sunar. Ancak her ne kadar dijital platformlar ve/veya sosyal medyadaki tüketim nesneleri bireyler için biriciklik yanılsaması sunsa da boş zaman etkinliklerinin standartlaşma ve birbirine benzeme eğilimi ile kitleselleştiğinden söz edilebilir. Bu noktada tüketilen içeriğin önemi giderek azalmakta 'medium'un ve ‘medium'da geçirilen zamanın önemi artmaktadır. Özellikle küresel kapitalist söylem çerçevesinde eğlence olgusunun kitleselleştiği bir dönemde boş zamanın tüketim endüstrisi tarafından kuşatılması hizmet sektörünün post-endüstriyel dönemde bireyin salt parasına değil zamanına da göz diktiğini gösterir. Nitekim günümüz ağ merkezli boş zaman 
kavramı, "hızlı boş zaman”a (Viñals-Blanco, s.170) dönüşerek anlık zevklerin deneyimlendiği bir süreci niteler. Bu süreçte dijital teknolojiler bireye "ayrı birlikte yaşama" (Flichy, 1995) ya da "birlikte yalnız kalma" (Turkle, 2011) gibi farklı deneyimleri yaşattığı ifade edilebilir (López-Sintas, Rojas de Francisco \& García-Álvarez, 2017).

\section{ARAŞTIRMANIN YÖNTEMI}

Çalışmada yöntem olarak nitel araştırma yöntemlerinden biri olan derinlemesine mülakat tekniği kullanılmaktadır. $\mathrm{Bu}$ araştırmada, televizyon izleme pratiğinde meydana gelen değişimin tüketim ve yaşam tarzı olguları bağlamında değerlendirilmesi amacıyla, 10 Haziran - 25 Eylül 2020 tarihlerinde gerçekleştirilen görüşmelerde yarı yapılandırılmış olarak 10 temel soru hazırlanmıştır. Sorular görüşmeler sırasında daha detaylı hale getirilerek ve katılımcıların ifade yeteneğini güçlendirmek için çeşitlendirilmiştir. Araştırmaya görüşmeler sırasında sorular geliştirilerek derinlemesine mülakat özelliği kazandırılmıştır. Çalışmanın örneklemini İstanbul'da yaşayan ve Netflix kullanan 12 kişi oluşturmaktadır. Örneklemin İstanbul ile sınırlandırılma nedeni farklı kültürel ve sanatsal etkinliklerin niceliksel olarak diğer şehirlerden daha fazla olması ve katılımcıların erişiminin daha kolay olabilmesidir. Ayrıca İstanbul'un kozmopolit yapısı farklı kültüre sahip insanlara ulaşmayı kolaylaştırmaktadır. Orta sınıf mensubu katılımcılar, meslek, gelir düzeyi ve ikamet ettiği çevre başta olmak üzere sınırlandırılarak tesadüfi/rastgele örneklem yöntemiyle ve cinsiyet eşitliği sağlanması amacıyla 6'sı kadın, 6'sı ise erkek izleyici arasından belirlenmiştir. Bu çalışmanın amacı yapılan araştırmanın genelleştirilmesinden ziyade bireysel anlam üretimine yönelik çoklu okumalara imkân sağlamaktır. Nitel araştırmalarda örneklem grubunun sayısal hacminden çok bulgular sonucu yapılandırma niteliği daha önemlidir (Jensen ve Rosengren, 2005: 136). Bu sebeple Netflix dizisi izleyen 12 kişi ile yapılan görüşmeler içerik tüketiminin çoklu okumaları için bir yol haritası oluşturmaya yeterli olduğu düşünülmektedir. Bu haritanın oluşturulması için katılımcılarla yapılan görüşmeler 31 - 52 dakika arasında yüz yüze (pandemi nedeniyle online) olarak gerçekleştirilmiştir. Çalışmada katılımcılar "K" ifadesi ile kodlanmakta ve ilk katılımcı $\mathrm{K}_{1}$ son katılımcı ise $\mathrm{K}_{12}$ ile gösterilmektedir.

Tablo 1: Araştırmaya Katılan Kișiler

\begin{tabular}{|l|l|l|l|l|}
\hline Katılımcı & Yaş & Cinsiyet & Meslek & İkamet \\
\hline $\mathrm{K}_{1}$ & 39 & Kadın & Öğretmen (Kamu) & Ataşehir \\
\hline $\mathrm{K}_{2}$ & 28 & Erkek & Akademisyen & Kadıköy \\
\hline $\mathrm{K}_{3}$ & 28 & Kadın & Drama Eğitmeni & Kadıköy \\
\hline $\mathrm{K}_{4}$ & 27 & Erkek & Akademisyen & Bakırköy \\
\hline $\mathrm{K}_{5}$ & 32 & Kadın & Yoga Eğitmeni & Şişli \\
\hline $\mathrm{K}_{6}$ & 38 & Erkek & Satıs Uzmanı & Küçükyalı \\
\hline $\mathrm{K}_{7}$ & 36 & Kadın & Öğretmen (Özel) & Bağcılar \\
\hline $\mathrm{K}_{8}$ & 33 & Erkek & Oyuncu & Beşiktaş \\
\hline $\mathrm{K}_{9}$ & 29 & Kadın & Sosyal Medya Uzmanı & Erenköy \\
\hline $\mathrm{K}_{10}$ & 31 & Erkek & Satıs Uzmanı & Kadıköy \\
\hline $\mathrm{K}_{11}$ & 41 & Kadın & Oyuncu & Bahçeşehir \\
\hline 554 & & & & \\
\hline
\end{tabular}




\begin{tabular}{|l|l|l|l|l|}
\hline $\mathrm{K}_{12}$ & 26 & Erkek & Lojistik Operasyon Sorumlusu & Beylikdüzü \\
\hline
\end{tabular}

\section{ARAŞTIRMANIN BULGULARI}

Bu bölümde katılımcıların, boş zaman aktiviteleri, kültürel beğeni ve izleme pratiklerini hangi çerçevede oluşturdukları ve nasıl yapılandırdıklarına dair ifadeleri ve düşünceleri incelenmektedir. Bulgular kültürel beğeni ve (yeni) yaşam biçimi bağlamında değerlendirilmek üzere tartışılmadan önce, kültürel beğenilerin yapılandırılmasında sosyal çevrenin gücünün sorgulanması ve etki düzeyinin açığa çıkarılması amacıyla, dijital platformlar ile (yeni) orta sınıf arasındaki etkileşim düzeyi incelenmiştir.

Boş zaman etkinliği olarak televizyon izleme pratiğinde meydana gelen değişimin değerlendirilmesine yönelik sorular 5 tema ile şekillendirilmektedir. Bu temalar, toplumsal uzam içinde bireyin kendini konumlandırmas1/ sosyal ilişki ağı/ kültürel beğeni ve içerik değerlendirmesi/ yeni yaşam biçimi-hayat tarzı/ (yeni) izleme pratiği başlıklarından oluşmaktadır. Bu temaların bütünü çalışmada yer alan katılımcıların genel olarak farklılaşan izleme pratiklerindeki değişimlerin değerlendirilebilmesi amacıyla oluşturulmuştur. İlk temaya bakıldığında katılımcıların kültürel tüketim pratikleri bağlamında kendilerini olmak istedikleri kültürel sınıf içinde konumlandırdıkları ve üst-kültüre ait sanatsal içerikleri deneyimleyen bireyler olarak tanımladıkları söylenebilir. Ayrıca Netflix ve geleneksel medya içeriklerini farklı şekilde konumlayıp kendi kültürel sınıfındaki insanların yapmayacağı bir eylem olarak görürler, ama pratikte geleneksel medya içeriklerini de tüketirler. Katılımcılar aşağıda belirtilen tabloda yer alan ifadeler bağlamında okumalar yapmaktadır.

\subsection{Bireyin Kendini Konumlandırması}

K1: "Televizyonun internete bağlanma işi olduğundan bu yana televizyon izlemiyoruz. Orada bize sunulan içerikler bize hitap etmiyor. Zevkime hitap etmiyor. Orada ne izlenebilir ki televizyonda..."

K2: "Televizyon içeriklerinde benim yaşam tarzıma ve ilgilerime uygun içerik bulamıyorum... Kapitalist düzen gerçekten bütün bu ayrımcllıkları besleyen bir düzen. Örneğin, azınlık gruplarının o şekilde kalmasını sağlayan bir düzen. Ama ne yazık ki bir taraftan kapitalist düzen özgürleştirici çünkü ne olursan ol gel dediği için herkes kendi öznelliği ile kendine ait alanını kurma imkânı sunuyor. Eşcinseller örneğin. Bir taraftan sömürünün içine gireceklerdi ama bir taraftan taşradan kurtulup şehrin içine gitmişlerdi insanlar ve kendilerine ait mekânlarda buluşmuşlardl. Bir şeyler tüketebilecekleri alanı da kapitalizm sağlıyor. Şu an gittikçe yükselen trendde toplumsal mücadeleler ister istemez kendini zorla olsa kabul ettiriyor ve bununla ilgili içerik ürettiriyor. Bende o içeriklere ulaşmak istiyorum."

K3: "Karantina dönemine kadar neredeyse sıfır. Ama şu an arka planda açık. Şu an Masterchef izliyorum. Televizyon izlemek keyif vermiyor... Geleneksel medyada içeriği beğenmediğim için ve Netflix'in içerikleri daha nitelikli olduğu için kızıma o içerikleri izletiyorum... Televizyondaki içerikler bizim kültürel normlarımız çerçevesinde doğru kabul edilen şeyler. Netflix'te iş biraz daha evrenselleşebiliyor."

K4: "Son üç senedir televizyon izleme alışkanlı̆̆ım azaldı neredeyse hiçe yakın televizyon izlemiyorum. Kendi gündemini kendim yaratma çabası nedeniyle izlemiyorum eğlence programlarl olsun, siyasi programlar olsun gündelik hayattaki ihtiyaçlarıma hitap etmiyor ben bana daha uygun olduğunu düşündüğüm niş şeyleri YouTube'da ya da farklı dijital 
platformlarda buluyor oluyorum. (...) Son üç beş yılda televizyonda yapılan yayınlar bana çok zehirli gelmeye başladı. Zaten çocukluktan itibaren çok ă̆ır bir dizi izleyicisi değildim. Televizyona sadece bilgilenmek amacıyla bakıyorudum... Netflix'e işe başladıktan sonra üye oldum çok büyük bir ücret olmasa da maddi olarak rahatladığımı hissettiğim zaman üye oldum."

K5: "Televizyon izlemiyorum. Uzun süredir izlemiyorum aslında. Reklam izlemek istemiyorum, çok uzun, çok sıkıcı, özgün içerik yok. Çok kalitesiz işler var televizyonda Netflix izledikten sonra, yabancı dizileri izledikten sonra Türk yapımlarına tahammül edemez oluyorsun. Daha öncesinde de CNBCe'de yabancı yapımlar izliyordum. Gossip Girls'i vb. gibi dizileri izliyordum... Netflix'e para ödemdem beni rahatsı etmiyor. Hizmet alıyorum ve hakkın veriyor. Çok pahalı olmadı̆̆ı müddetçe sıkıntı yok. Bir kahve parası."

K7: “Televizyon izlemiyorum. Youtube'da taknllyorum. Kendimin kontrol edemediği şeyleri sevmiyorum. Çok uzun zamandır televizyon izlemiyorum. İzlemiyor değilim ama eşim izliyorsa bakıyorum. Eşim Çukur izleyince bakıyorum bazen. Tivibu'daki belgesel kanalları da hoşuma gidiyor. Aşk-ı Memnu sonrasında dizi takip etmemeye başladım. Çukur eğitimciye ters geldiği için sevmiyorum. Mesela tarihi dizileri izlemeyi çok seviyorum. Öğrenciler övüyor, izliyorum ama tabi sonrasında bırakıyorum. Diriliş vb. dizileri hepsini izlemesem de izliyorum. Şu an Uyanış Selçuklu dizisini izledim. Öğrencilerim çok övdü fikir sahibi olmak için izledim. Şiddet içeriği çok fazla ama beğendim. Şu an tek takip ettiğim dizi Menajerimi Ara'yı izliyorum. Karşılaştırmak için."

K8: “Anneannemim apartmanı 60 yaş ve üstü. Binada internet kullanan yok. Onların hepsi televziyon izliyor. Bu da geleneksel medya kullanıcılarının kimler olduğunu gösteriyor. Kendi dilinde, bildiği oyuncuyu izlemek ister geleneksel medya kullanıcıları. Bunun da eğitim ile ilgisi var. Başta üniversite ve üstü Netflix kullanırken şimdi lise ve üstü kişiler izliyor. Yani televizyon biraz daha orta yaş ve üzeri için. Netflix daha genç kesime hitap ediyor. İzleyici kitlesini Total ve AB olarak değerlendirebiliriz. Belki yirmi sene sonra biz o avam kesim olarak Netflix izliyor olacağız, onun yerine ise bambaşka bir şey gelecek."

K9: "Dizilerin sürelerinin uzaması ve içeriklerinin muhafazakârlaşması sonrasında televizyon izlemiyorum. Her dizide şiddet var. Ilerlemeyen konu var. Sürekli tartışan ve ağlayan insanlar var. Bu sebeple izlemiyorum sinirlerimi bozuyor. Netflix'te tüketemeyeceğiniz kadar çok içerik bulunuyor. Orada istediğim beğendiğim şeyi seçiyorum. Eskiden televizyon izlerdim ama son üç yıldır gittikçe azalan bir şekilde izlemeyi bıraktım. Şu an da sadece Netflix izliyorum. Burada bu kadar acıklı hikâyeler yok."

K10: “Televizyon seyrediyorum. Ancak son 2 yılda bu izleme oranımda büyük bir düşüş olduğunu söyleyebilirim. Şu an da sadece Tv 8'deki Masterchef'i ve haberleri takip ediyorum. Eskiden Çukur izlerdim. Ancak son 2 sezondur takip etmiyorum. Olayların gittikçe saçma hale dönüşmesi diziden uzaklaşmama neden oldu. Ulusal kanallardaki RTÜK tarafindan uygulanan birtakım sinırlandırmalar bu kanalları takip etmekten vazgeçmeme ve Netflix'e yönelmemi sağladı. Netflixt'e ulusalın aksine gerçek hayattakine daha yakın içeriklerin olduğunu düşünüyorum. İnsanlar içki içebiliyor ya da istedikleri gibi konuşabiliyor vs. ”

K11: "Televizyon izliyorum. TRT 2, TLC, FOX TV, ID, History Channel ve Discover Channel gibi kanalları izliyorum. Ulusal kanallardaki diziler hantal, uzun ve ağırlıklı olarak duyguları harekete geçirmek üzerine temellendiği için ulusal kanallarda dizi seyretmeyi tercih etmiyorum. Bazen arkadaşlarımın oynadı̆̆ dizilerde oyunculuklarına bakmak için göz ucuyla 556 
bakıyorum ancak düzenli bir dizi izleyicisi değilim. Netflix'in dizileri süre ve içerik olarak daha çok beğeniyorum. Kısa, reklamsız ve merak unsuru yaratan öğeler içeriyor."

K12: "Televizyon izlemiyorum. Ailemle yaşarken evde her zaman açık olurdu ancak tek başıma yaşamaya başladığımdan beri bir yayınım yok. Sadece Netflix izliyorum. Orada bulamadı̆̆ım içerikleri Youtube ya da diğer indirme sitelerinden ulaşlyorum. Televizyon çok orta yaş annebaba işi geliyor bana... Ne izleyeceğime benim karar verdiğim özgür bir ortam varken neden televizyon izleyeyim ki?"

Formations of Class and Gender: Becoming Respectable adlı çalışma (1997, s.238) bireylerin "orta sınıflılığı imleyen seçkin ve sofistike stil sunmak için emek harcadığını", Toward a Theory of Status Consumption in Less Industrialized Countries adlı çalışma (2010, s.251) ise, "kültürel sermayesi yüksek grubun batılı hayat tarzı miti etrafında kültürel farklılıklarını gösterirken, daha düşük kültürel sermayesi olan grubun tüketim alanlarını yerlileştirdiğini” belirtir. Bu bağlamda orta sınıf bireylerin boş zaman etkinliklerinde ekonomik olarak alt sınıftan farklılaşarak içerik tüketimini gerçekleştirdiği televizyon izleme pratiği bireyin kendisini kültürel sermayesi yüksek olan gruba yakın şekilde konumlama isteği biçiminde gerçekleşir. Weber'e göre yukarı doğru ilerleyen sosyal hareketlilik beraberinde toplumsal saygınlık ve sosyal statünün yükselmesi imkanını içinde taşır. Bu nedenle genellikle ekonomik güç ile ilişkilendirilen statü gruplarının asal taşıyıcılığını mülk sahiperi belirler. "Bu gruplar, gelir ve meslekler nedeniyle zengin, yoksul, eğitimli, eğitimsiz statü grupları olarak kendilerine özgü bir yaşam tarzı oluşturur ve kendilerini diğerlerinden ayırırlar. Yüksek statü grupları, ahlaki yargı ve değerleri de içeren piyasa ve tüketim kurallarına göre kendi yaşam tarzlarını sembolize eden malları edinmeye çalışır ve kendini diğerlerinden ayırır" (Arslan, 2012, s. 60). Kültürel beğeni ile ekonomik sermaye arasındaki derinlikli ilişki bireyin kendisini yerel olandan -geleneksel olandan- uzaklaştırıp evrensel ya da Batılı-modern- olana doğru kaydırır. Katılımcıların salt Türkiye'nin kültürel normları çerçevesinde sıkıştırılmış bir izleme pratiğini reddetmesi ve küreselleşen dünyada evrensel meselelere, bakışlara, hikâyelere ulaşma isteklerini Netflix üzerinden gidermeye çalıştıkları söylenebilir. Araştırmada katılımcıların yanıtları incelendiğinde geleneksel televizyon içerikleri ile siyasal iktidarın denetim mekanizmaları arasında çok güçlü bir ilişki mevcuttur. Bu durum bireylerin özgürlük alanlarına bir müdahale olarak görülmekte ve alternatif yollar aramalarına neden olmaktadır. Zira geleneksel televizyonun siyasallaştığını ve beraberinde muhafazakârlaştığını aktaran katılımcılar içeriğinde bu nedenlerden dolayı kalitesizleştiğini ve toplumun tamamını temsil etmediğini de belirtir. Temsil pratikleri açısından geleneksel medya içeriklerinde toplumun azınlık gruplarına dair uyguladığı yasaklayıcı politikaların reel toplumsal yaşamda varolan mücadeleleri yok sayarak göstermemesi bireylerin Netflix dizilerine olan ilgilerini seçimden ziyade bir zorunluluk olarak yöneldiklerini gösterir. Bununla birlikte katılımcıların çoğu televizyon izlemelerine rağmen bu pratiği yerellikle ilişkilendirmeleri nedeniyle izlemediklerini iddia etmekte ancak belirli dizilere yönelik soruların sorulduğunda kendi iddialarını çürüttükleri görülmektedir. Geleneksel medya içeriklerinin bütün katılımcılar tarafından aşağılanması ve kalitesiz olarak nitelenmesi bireylerin aşağı-olan pratiği yapmalarına bir engel olarak görülebilir. Bu bağlamda kendisini aşağı bir konumda tanımlamak istemeyen birey hem televizyon içeriklerini reddeder hem de küresel içeriklerin olduğu medyaya doğru yönelir. 


\subsection{Sosyal İlişki A ̆ğ}

K4: "Herkes çevrenizde konuşuyor ve siz o konuşmalardan uzak kallyorsunuz bu bir baskı değil ama bu çok büyük bir etki ama aradan bir yıl geçtikten sonra çok dönemli olmadığına karar verdim yani sonuçta sohbetten uzak kalma bir noktada tabi bir dışlanmışlı etkisi yaratıyordu bunu engellemek istemiştim. Netflix'e üye olmadan önce arkadaşlarımla konuştuğumda sanki orada bir dünya varmış ve ben onu kaçırıyormuşum gibi hissediyorum ama gereksizmiş aslinda..."

K9: “Bazı arkadaşlarımdan Netflix'i duymuştum. Onlar sürekli oradaki dizilerden bahsetmeye başlayınca merak ettim. Birkaç defa arkadaşlarımla izledim sonrasında üye olmaya karar verdim. Insan ister istemez sohbetin gerisinde kalmak istemiyor sonrasında da içeriklerinin daha iyi olduğuna düşünmeye başladım. Şimdi de birbirimize önerilerde bulunuyoruz. Üstüne konuştuğumuz zamanlar oluyor çok uzun olmasa da muhabbete giriş aşamasında 10-15 dakika konuşuyoruzdur."

K10: "Netflix'i tercih etmemin nedenlerinden biri arkadaşlarım. Çünkü onların ettiği sohbetin dışında kalıyor olmak bir süre sonra sizin de aslında o içeriye ulaşmamız gerektiği hissiyatı doğurmaya başllyor. Bir noktada gündem dışında kalmış oluyorsunuz yani..."

K11: "Benim Netflix üyeliğim bir arkadaşımın şifreyi paylaşması ve bir dizi önermesi ile başlad. Internetten onu bulmak zaman allyordu. Yüklenmesi yüklenememesi ve hep önümüze çıkan reklamlar sıkıcı oluyordu. Bir süre sonra platformdaki içerik hoşuma gitti ve üye olmaya karar verdim. Netflix'e benim arkadaşlarım pandemi dönemi itibariyle üye olmaya başladılar. Bu sebeple bizim sohbetlerimizin ana konusu haline hiç gelmedi bu durum. Sadece birbirimize öneride bulunduğumuz zamanlar oldu ama sonrasında uzun uzun hiç konuşmadık. Ya da bu platformu olmayanlara Aaaa! Sen de neden yok şeklinde bir söylem geliştirmedik."

K12: "Netflix'e arkadaşlar grubumun önerisi ile üye oldum. Sürekli oradaki dizilerden bahsedip duruyorlardl. Bir süre sonra sohbete giremez oldum. Üye olduktan sonra bir sistem geliştirdik. Biz arkadaş grubumuzda sürekli birbirimize önerilerde bulunup hangi diziyi izleyeceğimize dair paylaşımda bulunuyoruz. Hatta aramızda şöyle bir durum geliştirdik. Biri izlemezse pisliğine spoiler veriyoruz. İşin tüm heyecanını kaçırıyoruz. Bu durum belli bir rekabet yaratıyor aramızda ĕglenceli oluyor.”

K1: "Netflix'i arkadaşlardan duydum. Onlarla Netflix içerikler üzerine konuşuyoruz, tartışıyoruz. Dizi seçimimde arkadaşımların önerileri oldukça belirgin.”

K5: "Bütün arkadaşlarım üye. Netflix yapımları üzerine sürekli konuşuyoruz. Şu işi kesinlikle izleyin, kadın harika, şu adam harika gibi. Daha önceden de konuşuyorduk.”

K8: "Illk üye olmamın nedeni popülariteydi. Birisi kaydoluyordu ve Instagram hikâyesinde paylaşıyordu ve bir şekilde o virüs bana bulaştı ve üye oldum. Üye olma nedemin insanların onu yüceltmesi... Çevremde üye olmayan arkadaşım yok. Ister istemez Netflix'teki herhangi bir şey hepimizin insan ilişkilerinde konuşacağı bir konuyu doğuruyor. Bu anlamda iletişim gücü ve sosyallik veriyor. Netflix dizilerinin sosyalleşmenin bir parçası olduğunu düşünüyorum. Bu yüzden aslında hepimiz bir şey çok güzel dendiği anda ona saldırlyoruz ki ertesi gün iş yerine gittiğimiz zaman konuşacağımı bir konu olsun." 
K2: "Gündemde olan ve konuşulan içerikleri yakalayabilmek için üye oldum. Çăga tanık olmak ve ayak uydurabilmek için üye oldum... Arkadaşlarımın çoğu Netflix e üye. Onlarla içerikler üzerine kendi hayatlarımızın kesiştiği noktalar üzerine konuşuyoruz. Kendi yaşam tarzıma uygun içerikleri izlemek istiyorum. Kendimi muhalif, insani değerlere önem veren ama iktidar baskısı karşısında dayanışma içinde olmaya ve birleşmeye bir birey olarak tanımlıyorum. Üye olmamda çevrenin etkisi muhakkak olmuştur. Çünkü sürekli konuşuluyor."

K3: "Arkadaş tavsiyesi. Internetten izlediğim bir dizi vardı, bir arkadaşım "aaa bu dizi Netflix'te var, istediğin zaman durdurabiliyorsun, kaldiğın yerden devam ediyorsun, her seferinde uğraşmıyorsun" dedi. Işs yerimde herkes üye. Arkadaşlarımla diziler üzerine konuşuyoruz. Molalı çalışma sisteminde çalışıyordum. Bu molalarında Netflix izleyen kişiler vardl, bazen bende yapıyordum bunu. İlk popüler olduğu zamanlar bu sohbet çok fazla dönüyordu."

K6: "Tanıdıklarımın hepsi Netflix'e üye. Onlarla Netfix dizileri üzerine konuşuyoruz. Arkadaşların tavsiyesi üye olmamda etkili olmuştur."

Kültürel sermayeyi sosyal sermayeye dönüştürme sürecinin nasıl işlediğini anlamak için DiMaggio'nun Classification in Art (1987) çalışmasına bakılabilir. DiMaggio'ya göre, modern toplumlardaki en önemli değişiklik, farklı sosyal ilişki ağ türleri arasında etkileşimi sürdürmek için gerekli kültürel sermayenin temel biçimlerini sağlamada genellikle kitlesel üretilen kültürün rolüdür. Bu süreç, bu sosyal ilişki ağları artan coğrafi hareketlilik ve eskiden akrabalık ve uzamsal yakınlık etrafında merkezlenmiş yerel topluluklara özgü geleneksel bağların azalması bağlamında dönüştürüldükçe daha da önem kazanmaktadır (Lizardo, 2006, 781). Bu noktada televizyon, her ne kadar sosyalleşmeyi engelleyen bir özelliği içinde taşısa da toplumsal etkileşimi sağlayan ve sohbet başlatıcı bir araç da olmuştur. Öyle ki iletişim bilimlerinde televizyon çalışmalarında televizyonun kültür ile ilişkisini ele alan çalışmalar da bunu doğrular niteliktedir (Newcomb, 1994; Tichi, 1991). Dijital yayın platformlarıyla birlikte değişmeye başlayan izleme pratiklerinde televizyonun konuşma tetikleyicisi ve bireyi kapalı bir mekâna bağlama özelliklerine vurgu yapılır (Morrison ve Krugman, 2001). Özellikle farklı mekânlarda aynı izleme deneyimi yaşayan kişilerin tüketim sonrası ürünler üzerine konuşma ihtiyacı sosyalleşmenin niteliksel özelliğinden ziyade niceliğindeki değişimi gösterir. Başka bir deyişle, Manley’in belirttiği gibi günümüzde bireyler içerik tüketimlerini arkadaşlarıyla konuşabilmek için tercih ederler. Bu durum ise içerik tüketimindeki miktarın artmasına neden olabilir. Zira dijital platformlardaki içeriğin eşzamanlı tüketilmesi popüler olanın üzerine konuşabilmek için bir olanak yaratarak birey, sosyal aidiyet ve dolayımlı bağlılık firsatlarından yararlanabilir (Morabito, 2013). Bu bağlamda bireyin kendi sosyal gruplarında bu tür bağlılık ve aidiyet duygularını kuramaması dolaylı olarak sosyal ilişki ağından uzaklaşmasına neden olabilir. Weber'e göre statü grupları ekonomik ve/veya kültürel güç ilişkileri üzerinden kendi yaşam tarzlarını oluştururlar. Böylece bireyler bu tür bir yaşam tarzı içinde geliştirdikleri sosyal ilişki ağında diğerlerini benzer faaliyette bulunmadıkları ya da ortak kesişim noktalarında bulunmadıkları için dışarıda bırakabilirler. Bakıldığında bütün bu süreç, o gruba dahil olan kişilerin sahip oldukları kaynakları (Netflix vb.) kullanım ve tüketim biçimleri ile ilişkili olduğundan kaynağa sahip olmayanlar dışarıda kalabilir.

Araştırmada katılımcıların çoğu Netflix’e arkadaşlarının önerileri ile üye olmaya başladıklarını, sohbetlerinin merkezini oluşturmamasına rağmen iletişimlerini büyük oranda etkilediklerini ifade ederler. Sosyal dişlanmaya maruz kalmamak ve konuşulan içeriğin güncelliğini 
sağlayabilmek için platforma üye olduklarını belirtirler. Tüm katılımcılar bu durumu baskı olarak değerlendirmese de bir etkisi olduğunu ifade ederler.

\subsection{Kültürel Beğeni ve İçerik Değerlendirmesi}

K4: "Dijital platformlardaki en güzel özellik WhatsApp'tan paylaş deyince dizilere oradan ulaşabiliyor olmanız televizyon dizilerinde bu tip şeyler olmuyor. Türk dizileri çok basmakalıp hep aynı konular işleniyor. Ama platformda format olarak farklı ve özgün bir içerik var. Süreler daha kısa, politik angajmanı olan ya da olmayan birçok insan için farklı beğeniler sunan malzemeler üretiliyor. Politik olarak bazen yanlış içeriklerde üretilebiliyor. Ama hep belirli bir hayat tarzını sunmuyor. Eşcinsellik, cinsellik, alkol gibi unsurlar var. Dizginlenmemiş içerik izleyiciye özgürlük alanı sunuyor. (...) Netflix'te Aşk 101 ve Atiye dizilerini izledim. Daha önce Sex Education diye bir gençlik dizisi seyretmiştim bakalım Türkiye'de bunu nasıl yapacaklar diye merak ettim ve onun için izledim"

K9: "Netflix'i kendi istediğim zaman izleyebilme özelliği nedeniyle tercih ettim ilk olarak ama içerik de önemli tabi. Televizyonda haberler sonrası gece yarısına kadar bir dizide ne olacă̆ını anlamaya çalışıyorsunuz oysa dijitalde neredeyse sezonu yarlamış oluyorsunuz. Hem zamandan kazanıyorsunuz hem izlediğiniz şeyin daha kaliteli olduğunu anlıyorsunuz. En azından kişiler saatlerce boş boş birbirine bakmiyor. Sürekli bir hareket var. Bir de konular daha özgür sanki eşcinsellik, farklı kültürlerin özellikleri kadın erkek ilişkileri gibi. Bunların hiçbirini televizyonda bulamazsınız.

K10: "Netflix'in kişiselleştirme özelliği çok iyi öncelikle TV+ ya da Tivibu gibi platformlarda kişiselleştirme yapılıyordu ama Netflix'in kişiselleştirmesi sizin ilgi alanınızın sınırlarının belirlenmesi noktasında daha belirgin. Beğeni türünüze göre yönlendirme yapıyor. Dizilerin içerikleri iyi ama filmleri beğenmiyorum. Dizilerde de yabancı yapımlar daha çok aksiyon içeriyor. Türk yapımlarımdan sadece Atiye'nin birkaç bölümüne baktım içim bayıldı. Ama yabancı dizilerde sürükleyicilik ve gerçeklik var. Televizyonda platformdaki kadar geniş bir yelpaze yok. Çoğu şeyi göremiyoruz. Gerçeklikten uzak..."

K11: "Dijitalde var olan havuzdan kendi zevkine göre içerik belirleyebiliyorsun ulusal da yayın akışını takip ediyor olman gerekiyor. Dijital bu anlamda bir özgürlük alanı yaratmıyor ancak sınırlı alanda ya da işte var olan havuzda birilerinin seçkisi arasından belirleme imkânı sağllyor. Dijitalde reklam izlemiyorsun ve zamanını sadece içeriğe ayırabiliyorsun. Ulusalda daha uzun zaman diliminde daha sınırlı bir içeriğe ulaşıyorsun. Ayrıca cinsellik, hikâye seçimi, kostüm ve karakter gibi özellikler dijitalde daha zengin. Blurlanan görüntü ya da kesilen diyalog yok! Keşke Trt 2 de filmleri kesilmemiş sahneler ile yayınlayabilse o zaman farklı arayışlar içerisinde girmem azalabilirdi."

K12: "Netflix’in benim belirlediğim kriterlere göre yönlendirme yapmasını seviyorum. Ulusaldaki içerik çok bayıcı... Diziler akmıyor, filmler dublajlı, yarışmalar arada eğlenceli ama onları da çok uzatıyorlar. Halbuki Netflix'te gençlerin yaşamlarına ve ilgi alanlarına göre her şeyi dizilerde gösteriyorlar. Cinsellik, içki, şiddet ve küfür hayata dair her şey var."

K1: "TV'de dizi izlemiyorum. Ama son zamanlarda Kırmızı Oda ve Masumlar Apartmanı'na şöyle bir göz ucuyla baklyoruz. Psikolojik içerikli olduklarl için tercih ettim. Farklı tarzda olduklarl için izliyorum aslında. Netflix daha geniş bir yelpazede içerik üretiyor... Geleneksel medyadaki içerikler çöp. Sürekli bir yaranma çabası, sapmasapan tavırlar" 
K2: "Istediğinize uygun tematik kanalları bumak biraz daha zor ancak bunlar kablolu yayılar ya da ücretli platformlarla alabileceğiniz paketler oluyor. Dijital platformlarda seçenek daha fazla, ilgi alanına uygun içerikler var. Ben mesela biraz dil olarak, söylemsel olarak daha temiz içeriklerin olduğu, şiddetin pornografik hale dönüşürrülmediği, kadınlara karşı ayrımcılık üretilmeyen yapımları televizyonda bulmak çok zor. Bütün diziler neredeyse toplumsal cinsiyeti yeniden üretiyor, oradaki şiddeti yeniden üretiyor, bütün kültürel kodlarl sivriltiyor. İktidar ilişkileri kaynakl senaryo içerikleri değiştiriliyor. Hakim olan iktidar tarafina daha angaje bir içerik var. Ama dijital platformlarda bunun alternatiflerini bulabiliyoruz. Sansürden kurtulmanın bir yolu. İzleme pratiği olarak da fark var. Birinde özellike takip etmen gerek, yayın akışına uyman lazım. Dijital platformda bir gecede tüm sezonu bitirebiliyorsun, bu çok konforlu bir şey. Uçucu da gelmeye başladı son dönemde, izlediğim şeyleri kafamda tutamıyorum mesela. Oturmuşum 8 saat bir sezonu izlemişim ama zihnimde kalmamıs. Biraz öyle hemen kullan at tüketimine de yaslanan bir şeymiş gibi gelmeye başladl. Ama bir taraftanda da daha iyi daha güzel bir şey."

K8: "Türk dizileri Türk insanını salak yerine koyuyor. Bunu birçok açıdan yapıyor: senaryo, çekim, süre, yarattı̆̆ karakter açısından yapıyor...

K3: "Şu an hiç izlemiyorum. Önceden Şaşıfelek Çıkmazl, Yeditepe İstanbul, İkinci Bahar, Avrupa Yakasi gibi dizileri izliyordum. Üniversiteye 2010, yurt hayatı vb. geleneksel medyadaki dizileri takip etmememde rol oynamış olabilir. Bizim yaş grubumuzda popüler olan Netflix dizileri olduğu için takibi bıraktım. Fark var ve yok. Netflix çok içeriğe sahip. Belki geleneksel medya içeriklerine benzer dizileri Netflix'te bulabilim ama Netflix dizilerini geleneksel medyada bulamiyorum."

K5: “Ístediğin şeyi istediğin zaman izleme özgürlüğü var. İçerik farkı var. Televizyondaki içerikler basmakalıp genelde. Uzun uzun bakışmalar, oyuncu olmayan kişilerin kalitesi yapımları oluyor genelde. Can Yaman'ın vücut gösterisini izlemek istemiyorum. Önceden daha kaliteli yapımlar vardı artık yok. Önceden Aliye, Avrupa Yakası, Aşk-ı Memnu vb. izlerdim ama artık izlemiyorum. Dijital platformlar daha farklı ve kaliteli içerikler üretiyor."

K7: "Televizyonda reklam çok fazla. Bu yüzden vakit kaybı geliyor. Aslında televizyon izlemeyi çok seviyorum. TRT 2'nin belgesellerini çok seviyorum. Bana hitap eden programı görünce kallyorum."

K6: "Netflix'te yabancı içerik, geleneksel medyada Türk dizileri izliyorum. Geleneksel medyada diziler çok uzatıyorlar; Netflix o kadar uzatmıyor, başı sonu var. Içerik olarak çok fark yok. Şiddet ve cinsel içerik Netflix'te sansür yok. Netflix'te bol bol gay ve lezbiyenlik var. Azınlıkların temsil edilmesi daha gerçekçi kılıyor. Netflix içeriklerini daha çok beğeniyorum. Daha sansürsüz ve gerçekçi. Mesela Diriliş Ertuğrul, Kara Murat'ın aynısı, böyle bir kılıç dövüş sahnesi yok ya, büyük beceriksizlik. Gerçekçi değil."

Yukarıdaki katılımcıların ifadeleri değerlendirildiğinde Bourdieu'nün sınıf habitusu kavramı ile derinlikli ilişkisi ortaya çıkar. Bourdieu'ya göre "bireylerin pratikleri, birbirleriyle ve çevreleriyle ilişkileri, konuşma biçimleri, yürüyüş tarzları, şeyleri yapma biçimleri" ile ortaya çıkar. Bu nedenle, kültürel pratiklerin ve beğenilerin analizi, görece homojen birey gruplarını, yani farklı sınıf habituslarını ortaya çıkartır. Çünkü zevkler, bireylere "mevkilerini hissettirir" (Karademir Hazır, 2014, s. 245). Zira "bireyin konumunu belirginleştirmek, pekiştirmek ya da 
ifade etmek üzere belirli normlara bağlı tüketim tercihlerine sahip olması (Aaker, 1999), bu davranışların ve onlara bağlı anlamların da sürdürülmesine neden olmaktadır. Böylece sosyal statü odaklı davranışlar aynı zamanda daha genel anlamda bireyin toplumsal uzam içinde kendisini sürekli olarak konumlandırması işlevi görmektedir. Bourdieu tarafından toplumsal sınıfların yeniden yorumlanmasıyla tüketime atfedilen işlev, bu anlamda tüketimin toplumsal konumlanma aracı haline geldiğini içermektedir (Topçu, Eroğlu \& Özer, 2020, s. 158)." Araştırmada 12 katılımcının 10'u televizyon izlemediklerini ifade etseler de görüşmenin bazı yerlerinde geleneksel medya içeriklerini tükettiklerini -farkında olmadan- belirterek televizyon izleme pratiğini aşağılayıcı bir eylem olarak tanımlar. Bu tür bir tüketim pratiğini yadsıma bireyin statüsüne zarar vereceği endişesini içerisinde taşıyabilir. Bu durum beğeni olgusu çerçevesinde de ortaya çıkar. Geleneksel medya çıktılarını aşağı bir konumda tanımlayan katılımcılar statülerini ekonomik bir konumda değil, toplumsal saygınlık gibi daha öznel bir çerçevede ilişkilendirirler. Öyle ki, Weber'in statü kavramı üzerinden değerlendirildiğinde aynı toplumsal statüye sahip bireylerin yaşam tarzı ve tüketim alışkanlıklarının benzerliği onları toplumsal olarak alt kesimden ayırarak farklı bir konuma yerleştirir.

Araştırmada katılımcılar çoğu televizyonda yerli dizi izlemediklerini içerik olarak yerli dizileri konu, süre, kostüm ve yaşam tarzı olarak sınırlı bulduklarını, bunun yanı sıra cinsellik, alkol ve kadın erkek ilişkileri bağlamında platformların daha geniş bir skalaya sahip olduğunu ifade ederler. Ancak katılımcıların çoğu ulusal kanallarda yerli dizi izlemediklerini belirtirken platformlarda yer alan yerli yapımları tüketmektedirler. Bu noktada mecranın yerli yapımların niteliğini değiştirdiğini düşünmektedirler. Katılımcılar içerik değerlendirmelerini televizyonun olumsuz, Netflix'in olumlu yönleri üzerinden gerçekleştirir. Geleneksel televizyon içerikleri benzer konuları oldukça uzun bir zaman diliminde verirken Netflix, katılımcılara göre özgün içerikleri daha kısa sürede izleyicilere verir. Bu durum izleyicilerin tüketim miktarının da aşırılaşmasına neden olmaktadır. Bireylerin boş zamanlarında maddi tüketimden ziyade maddi olmayan tüketime kayması da ilginç bir veridir. Günümüzde bireyler tüketim tercihlerini kendi zamanları üzerinden yapılandırırlar. Bu durumun siyasal ve ekonomik durum ile yakından ilişkisi mevcuttur. Katılımcıların kültürel beğenilerini gerçeklikten uzak olmayan (cinsellik, küfür, sigara, alkol vb.), azınlıkların da gösterildiği, politize edilmemiş içerikler üzerinden oluşturduğu diziler orta sınıf bireylere özgürlük alanı sağlar. Zira reel toplumsal yaşamda ekonomik ve siyasal alanda kendini özgür hissedemeyen, sıkışmış hisseden bireyler özgürlük hissini Netflix dizilerinde tadabilmektedir. Geleneksel yayıncılığın rijit yayın akışı ve ona itaat etme zorunluluğu da zamansal ve mekansal özgürlük olanağı veren dijital platformlara eğilimin bir diğer nedenidir.

\subsection{Yeni Yaşam Biçimi-Hayat Tarzı}

K4: "Dizi ve film izlemek dışında bisiklet sürmeyi ve kitap okumayı seviyorum. Bunların dışında konser ve tiyatroya gidiyorum. Sinema da gişe filmleri izlemiyorum çünkü onları torentten indirebiliyorum. Pandemi öncesi konserlere çok giderdim. Tiyatro biletleri daha uygun ücretli olduğu için de oyunları tercih ederdim. AVM'lere sıkışmayan etkinlikler bana kendimi iyi hissettiriyor. (...) Müzelere çok sık giderdim yani para ödeyeceğim ve keyifli vakit geçirebileceğim her aktiviteyi aslında yaptığımı söyleyebilirim son ü̧̈ haftadır 3-4 tane oyun gördüm geçen hafta gittim mesela tiyatroya..."

K9: "İş trafik vs çok yorucu oluyor. Boş zamanlarımda caddeye yakın olduğum için sahile iniyorum. Arkadaşlarımızla buluşuyoruz. Temiz havada olmak iyi geliyor. Arada sinemaya gidiyorum kapalı yerleri AVM'leri çok sevmiyorum. Orada kendimi sıkışmış hissediyorum. Bir 562 
de sinema bileti yemek falan derken çok da maliyetli oluyor. Fazla da başka sinema kalmadı o yüzden çok izlemek istediğim bir film olursa ya da arkadaşlarım önerirse gidiyorum. Klşları daha çok evde televizyon karşısında olayı tercih ediyorum."

K10: "Televizyon izlemek dışında sinemaya gitmeyi seviyorum. Yaz ayları hariç ayda iki sinemaya gitmeye çalışlyorum. Bazen ayda bir olduğu da oluyor. Onun dışında festivalleri seviyorum. Daha çok yeme-içme üstüne olanlarl; Sokak Lezzetleri ya da Kahve festivali gibi... "

K11: "Televizyon izlemek dışında sinemaya, sergiye ve festivale gitmekten keyif alırım. Kendim de bir festivalin yapımcılı̆̆ını üstlendiğim için tabiki o dönemde daha çok performans takip ediyorum. Konserler bunlar arasında en az olanları daha çok tiyatro oyunu, heykel, yontu, modern dans vs. Şimdi pandemi ve online olduğu için daha çok takip edebiliyorum. Hatta en son dün izledim. Pandemi öncesinde ise en son Şubat ayında arkadaşımın oyunu olan Deliliğe Övgü’ye gitmiştim. Pandemi öncesinde ortalama olarak yllda 10 ya da 12 performans izlediğimi söyleyebilirim.”

K12: "Bir şeyler izlemediğim zamanlarda arkadaş grubumla Counter Strike da Ps oynamayı ve birlikte taklmayı seviyorum. Birilerinin evinde ya da dlşarda sohbet edip taknliyoruz."

K1: "Eskiden müze gezmeyi çok severdim. Her boş günümde eskiden müze ziyareti vb. yapardım. Hafta bir bunlardan biri (sergi, müze, sinema, arkadaşlarla sosyalleşme) kesin olurdu. Yaşamsal koşulları daha fazlasını yapmamı engeliyor... Şimdi kitap okuyorum, televizyon izliyorum. Daha çok Youtube. Ev içinde daha çok vakit geçiriyorum.”

K5: "Önceden sinemaya gidip sosyalleşerdim. Yoga. Tiyatrodan sıkldım. Fiyatlar falan arttı, ekonomik anlamda çok etkiledi. Sinema da son zamanlarda çok pahaland, iki kişiye 100 TL vermek enayilik gibi geliyordu. Bir ay sonra Netflix'e gelen filme o kadar para vermek enayilik bence. Öncesinde bir kahve içip film izleyip sonrasinda bir yemek yiyip dişarda bir aktivite yapıyordum ama artık Netflix'te daha konforlu gelmeye başladı. Beğenmediğimi kapatıyorum, durduruyorum. Bekletip sonrasında izleyebiliyorum. Diğer kültürel aktiviteleri yapardım ama ekonomik sıkıntı engelliyor... Artık boş zamanlarımda neredeyse tamamen Netflix izliyorum. Aynı zamanda Yoga yapıyorum ve kitap okuyorum”

K8: "Ayda iki defa sergiye gidiyordum. Kitap okuyorum. Netflix olduğundan beri biraz sinema kültürü azald . 5 sene önceki ben filmin sinema salonunda izlenmesi gerektiğini savunurdu. Ama günümüzdeki gelişmeler evde izlemenin daha konforlu olduğunu hissettirdi ama hiçbir zaman sinemadaki konsantrasyonu yakalayamıoruz... Şimdilerde boş zamanlarımda Instagram video içerik üretiyorum. Dizi izliyorum. Bazen dizi izlemesem de saçma sapan Masterchef açıyorum. Başı ve sonu olmadiğ i için ne zaman açsam yakalayabildiğim bir şey. Bu anlamda o beni rahatlatan bir şey oluyor."

K2: "Sahne sanatlarına ayda 1 veya 2 kere gidiyorum. Haftada en az 2 kere dişarıda arkadaşlarımla oturuyorum. Konserleri takip etmeye çalışlyorum. Ve tek başıma bireysel olarak takllyorum... Bazen dışarda bazen bütün gün evde zaman geçiriyorum. Youtube videolarl izliyorum. Kimi zaman da evde film ve dizi izliyorum. Youtube'da da dizi izliyorum. Ülkenin durumu, belirsizlik, bizim gibi bu yaş grubundaki hemen herkeste karşılaştı̆̆ım gelecek kaygısı, belirsizlik, yaşamı nasıl devam ettireceğine dair öngörülmezlik hali. Sürekli bir kaygan zemin üzerinde hareket edip ne yapacă̆ımı da kestiremiyorum. O bir kaygı sebebi, sürekli ekonomik olarak kendimi nasıl geçindireceğim kaygısı. Travmatik haberler, toplumsal 
ayrımcılıklar gibi faktörler dışarı çıkıp sosyalleşmemi engelleyip evde vakit geçirmeme neden olan unsurlar."

K3: "Tiyatro ve sinemaya hafta bir gidiyorduk. Klzım olduktan sonra gidemiyoruz. Ama şu an kızımla müze geziyoruz, neredeyse bütün müzelere gitmişizdir. Bazen ekonomik olarak zorlayıcı olabiliyor. Özel bir tiyatro bileti minumum 45 tl ögrenci aldiysam onu da. Yoksa 75-80 TL zorlayıc olabiliyor. Sinema mesela ayda bir mutlaka tiyatro, 2 defa da sinemaya gidiyorduk, kızım olmadan önce."

K7: "Storytel üyeliğim var. Radyo tiyatrolarl var onlarl dinliyorum. Çocuk doğmadan önce müzelere her hafta sonu giderdik. Çocuk olunca gidemiyoruz... Boş zamanlarımda kitap okuyorum, kızıma masal kitabı yazıyorum. Ablam ve annemle vakit geçiriyorum, onlarla sohbet etmeyi seviyorum."

K6: "Her hafta sonu mangala, pikniğe gidiyoruz. Ev içi daha çok zaman geçiriyoruz. Evde daha rahat ediyoruz. Az gürültü, kalabalktan uzak daha rahat oluyor insan."

Yaşam tarzı kavramı marksist perspektifte bireyin sınıfsal konumuna göre belirlenen, onun beğenilerini, değerlerini ve pratiklerini şekillendiren bir olgudur (Sobel, 1981, s.7). Marks, insanın hayatı boyunca ekonomik alım gücünün çizdiği sınırlar çerçevesinde yaşamını şekillendirdiğini düşünür. Hatta, bu ortak ekonomik sınıfsal alanda bireyler diğer üyelerle benzer/ortak bir yaşam oluşturabilir. Marks'ın iddiasından hareketle farklı ekonomik sınıflarda konumlanan bireylerin benzer yaşam tarzlarını deneyimlemeleri olası değildir. Ancak ekonomik determinist bakış açısının sınırlı çerçevesi yaşam tarzlarını belirlemede önemli bir faktör olsa da tek başına yeterli değildir. Nitekim günümüzde ekonomik bağlamda toplumsal sınıflar arasındaki ayrımın artmasına karşın giderek sınıflar arası geçişin muğlaklaştığı söylenebilir. Özellikle 1990'lı yıllar sonrasında değişen ekonomi politikaları sonucu lüks tüketim pratiklerinin deneyimlenmesi ile yeni yaşam tarzları yaratılır. "Böylece alt ve üst sınıf arasındaki orta sınıfın konumu yeniden şekillenir ve alt orta ve üst orta sınıf olarak ikiye ayrılır. Bourdieu'ya göre, yükselen orta sınıf, tüketim kültürünün inşasında önemli rol oynayan "kültür aracıları"dır (Baloğlu, 2019, s.2881).” Bu bağlamda günümüzde toplumsal sınıf, soyut kavramlar kümesinden oluşan bir kavramdan ziyade, o sınıfı oluşturan bireylerin toplumsal ve kültürel pratiklerini deneyimledikleri ve bunları çeşitli sembolik araçlarla yapılandırdıkları bir yapıdır. $\mathrm{Bu}$ nedenle toplumsal sınıf ile ilgili araştırmaların verileri topluluğun topyekün eylemlerinde değil, gündelik yaşam pratiklerini, deneyimlerini ve beğenilerini inşa ettikleri Bourdieucu tarzla- bireysel alanlarda elde edilmelidir. Ancak şunu da unutmamak gerekir ki, bireylerin toplumsal ilişki ağları ve yaşam tarzları Marks'ın belirttiği üzere ekonomik sınıfsal sınırın belirlediği ölçütler çerçevesinde belirlenir. Bu durum gündelik yaşam pratiklerini alt, orta ve üst sınıfsal konumda yaşam tarzlarını şekillendiren bireylerin kültürel sermaye aracılığıyla kazandıkları kimlerini de sınıfsallaştırır (Karademir Hazır, 2014, s.234).

Kimliğin sınıfsallaştı̆̆ı yeni yaşam biçimi pratiklerinde yaşam tarzı kavramı sosyal sınıflar arasındaki güç ilişkilerini kültürel anlam ilişkilerine dönüştürür. Başka deyişle, bireylerin farklı yaşam tarzlarını içerimleyen toplumsal konumlarının değerleriyle kimliklerini, düşünce ve davranışlarını inşa ederken, kendi yaşam tarzlarının diğerleriyle aynı olmaması doğal bir süreç gibi anlamlandırılır. Tüm bu süreçte bireyin kendi ve/veya grubunun tekilliğini ayrıcalıklı konuma yerleştirmesi doğallaştırma sürecini destekler. Böylece farklı grupların tüketim pratikleri arasında inşa edilen ayrıcalıklık ya da ayrışma tüketim pratiğinin tekilliği, bireyin kendi (öz)alışkanlıkları gibi resmedilerek sembolik ya da simgesel tüketim araçlarıyla 
meşrulaştırılmaya çalışılır (Bourdieu, 2014, s.203). Keza Üstüner ile Holt'un Ankara' da üst orta sınıflarla yaptığı nitel çalışma da bunu destekler niteliktedir. Ankara'da orta sınıf bireylerin kültürel sermayesi yüksek grup, batılı hayat tarzı miti etrafında kültürel farklılıklarını gösterirlerken, daha düşük kültürel sermayesi olan grup, tüketim alanlarını yerlileştirmek suretiyle, ulusal sosyal hiyerarşideki pozisyonlara oynarlar. Yine, yerel olandan, "bayağı" dan ve "düzensizlik"ten kaçma isteğinin mekansal yansıması olan uydu kentler üzerine yapılan çalışmalar da bu kültürel hiyerarşinin varlığına işaret eder (Üstüner ve Holt, 2010, 51).

Araştırmada katılımcıların cevaplarının çoğunda yaşamın tarzlaşma eğilimi/çabası gözlemlenirken ve Üstüne ve Holt'un çalışmasına yakın veriler elde edilmiştir. 12 katılımcının 9'unda kültürel sermayesi yüksek grupların batılı hayat tarzı miti etrafında boş zaman pratikleri şekillenirken ekonomik olarak kaygan zeminde bulunan orta sınıfın kaygıları nedeniyle katılımlarının engellendiği ifade edilmektedir. Ancak ekonomik sıkıntı yaşamalarına rağmen kültürel pratikleri deneyimleme sıklıklarında bir azalma olduğunu belirten katılımcılar, gerektiğinde ücretsiz aktiviteleri takip edip gittiklerini belirtmektedir. Kültürel sermaye bağlamında incelendiğinde alt sınıfsal gruplardan ayrışma çabası olarak gözlenen bu çaba, Hjelmslev'in belirttiği üzere sanat eserlerine simgesel bağlamda sahip olma isteği olarak tanımlanabilir. Özellikle festival, sergi, müze ve sahne sanatları gibi üst kültür içeriklerini deneyimlediklerini belirten katılımcılar (yeni) yaşam biçimlerini ev içi / ev dışı olarak kategorize ederken ev içinde genellikle Netflix gibi platformlarda dizi içerkleri tüketirken ev dışında üst kültüre yakın kültürel praikleri deneyimler. Diğer 3 katılımcının gerek iş ve beğeni farklılaşma bağlamında arkadaşlarla sahil ve piknik alanlarında sosyalleşme ve dijital oyun oynama deneyimleri göze çarpmaktadır.

\section{5. (Yeni) İzleme Pratiği}

K4: "Bir diziye başladım mı bitirene kadar izliyorum. Geçen Unbelievable diye dizi izledim akşam dokuzda başladım sabah altıda bitirdim ve öyle kalktım. Mesela Call My Agent onu da bir hafta içinde falan bitirmiştim yani üç sezonu, seviyorum öyle bitene kadar izlemeyi... (...) Dizilerde filmlerdeki gibi bir yoğunluk olmadiğı için benim daha çok zamanımı alıyor. (...) Benim için zaman zaman Netflix evin hâkimi konumuna gelebiliyor hatta ben bazen pişmanlıkla izliyorum o diziyi çok zamanım gidiyor çünkü ama kendimi de izlemekten alamıyorum. Pandemide izleme sıklı̆̆ım arttı. Karantinada tükettiğim içerik 3-4 kat arttı. Bir dizinin 5 sezonunun orada olması patlamış misır etkisi yaratıyor. Hepsini tüketmek istiyorsunuz."

K9: “Ístediğim saatte istediğim şeyi izlediğim için Netflix kullanıyorum. Netflix’i parça parça düzenli olarak izleyebiliyorum. İş çok zamanımı alıyor. Bu sebeple akşamları ancak 2-3 saat izliyorum ama öyle sezonu tek günde bitirmem mümkün değil. Pandemide evden çalışırken daha çok izledim aslında 4-5 saat mesela... Daha önce belirlediğim ama bakamadı̆̆ım dizi ve filmlere baktım özellikle. Belgesel çok ilgilimi çekmiyor o yüzden izlemedim”.

K10: “Netflix’in kişiselleştirme özelliği beni daha çok izlemeye yöneltti. Eskiden Tv+ve Digiturk üyeliklerim vardl. Ancak orda böyle bir serbestlik yoktu. Şimdi kendi seçtiğim diziyi parça parça günde en fazla 3-4 bölüm olacak şekilde izliyorum. Daha fazlasını izleyemiyorum sıkılıyorum. Sadece pandemi döneminde evden çalışırken çok boş vaktim oldu orada belgesel vs de izledim bazen yaklaşık 6-7 saat izlediğim zamanlar oldu."

K11: "Netflix'e yönelmemdeki en önemli neden belirli bir havuz içerisinden seçim yapabilmek. ...Ulusal kanallarda var olan akışa uyum göstermeniz gerekiyor. Ben hafizasi kuvvetli bir izleyici olmadığım için sezonları biriktirmeyi tercih ediyorum. Çünkü sonraki sezonları aradan 
zaman geçtiğinde izlediğimde hatırlayamıyorum. Netflix'te işim olmadı̆̆ında 1 ya da 2 bölüm dizi ya da 1 film izliyorum ancak pandeminin ilk döneminde eve tıkıldığımız ve benim işlerim tamamen durduğu için bir bağımlılık oluştu. Günde 5 ya da 6 dizi ya da 2-3 film izlemeye başladım. Bu bağımlılık yavaş yavaş eski pratiğime döndü şu an da yine en fazla 2 saat izliyorum."

K12: “Netflix'te bir dizi yakaladım mı sezonu bitirmeden başından kalkmıyorum. Bu çoğu zaman sabahlamama neden oluyor. Özellikle pandemi döneminde şirkette covid çıkınca tedbir için 15 gün evde kaldık. O süre zarfinda 10 saate kadar dizi izleyip listemdeki tüm dizileri bitirdim. Ancak yeniden çalışmaya başlayınca sadece akşamları izleme alışkanlığıma geri döndüm."

K1: "Ĕ̆er güzel bir dizi varsa ve 4 sezonsa, o 4 sezonu birkaç günde bitirebiliriz. Çocuğum çok fazla izliyor şu stralar. Netflix olmadan önce geleneksel medya izliyordu ama şu an Netflix'i izliyor ama otomatik yeniden başlatma daha fazla içerik izlemesine neden oluyor. Bu aslında bizim için de geçerli yarın iş olsa bile yeni bölüm otomatik olarak başladığında bizi izlemek için dürtüyor ve izliyoruz."

K5: "Ĕ̆er beklediğim bir diziyse tüm günümü ayırlyorum. Genellikle dizileri bütün sezonu bir anda izliyorum. En son La Casa De Papel'i o şekilde izledim. Toplam 9 saat, sabahtan akşama kadar. Çünkü merak ediyorsun... Pandemi döneminde daha fazla Netflix dizisi izledim. Tüm gün eve kapanıp dizi izlediğim günler oldu."

K8: "Ekşi sözlük gibi platformlardan aldı̆̆ım bilgiler ya da değer verdiğim arkadaşlarımdan aldı̆̆ım tavsiyeler beirleyici. Oturup sabahtan akşama kadar tüm bölümleri izlemeyi seviyorum. Yoruyor ama yorgunluk aldiğın zevkin arkasında kalıyor."

K2: “Internette yapılan yorumlar Bantmag, Filmlovers gibi sitelerdeki eleştirel seçtiğim içeriklerde belirleyici oluyor. Genelde parçalara bölüyorum dizi uzunsa. Ama 20 dk lik dizilerse bir oturuşta AŞK 101 bölüm 1 saatti ama tüm gün izledik. Ondaki fark aile ile ortak bir şey yapıp onun üzerine konuşabilmek etkili oldu. İzlerken sıkılmadım. Dizi hoşuma gittiyse merak ediyorum, o yüzden izlerken yorulmadım."

K3: "Dizi izlemeden önce bitmiş bir dizi ise kaç sezon diye baklyorum 4-5 sezonsa başllyorum. Diziyi eşimle başladıysam parça parça izliyorum. Ama kişisel başladıysam sezon sezon izliyorum."

K7: "Bir sezonu bir günde bitiriyorum. Örneğin Atiye dizisini beğendim ve bir günde bitirdim."

K6: "Netflix benzer içerik önerdiği için sevdiğim film, dizileri öneriyor. İlk başta internetteki yorumlara bakıyorum, keza popüler olması da dikkatimi çekmesi için etken ama beğenmezsem kapatıyorum. Genellikle gelen sezonları tek seferde izliyoruz."

Kanada'nın Toronto Star gazetesinden Raju Mudhar'1n Netflix Etkisi ${ }^{2}$ olarak belirttiği yeni izleme pratiği bir anlamda "açık büfe" tüketime doğru gidildiğine işaret etmektedir. Benzer şekilde Manley ise kişilerin sosyalleşmeden kaçınmak yerine sosyalleşebilmek için izleme pratiklerini değiştirdiğini belirtir (Manley, 2013). Nitekim Netflix'in yaptığı incelemelere göz atıldığında bir sezonun tüm bölümleri eş zamanlı yayınlanan dizilerin genç ve orta yaş izleyiciler arasında oldukça yaygın olduğu söylenebilir (Matrix, 2014, s.119). Dijital yayın

\footnotetext{
${ }^{2}$ https://www.thestar.com/entertainment/2013/10/16/the_netflixication_of_all_media.html 566
} 
platformlarının giderek ucuzlaması ve erişilebilir olması içeriklerin zaman ve mekândan bağımsız izlenebilmesine olanak sağlar. Katılımcıların çoğunun ortak cevaplarından olan özgürleşme ve içeriği yönetebilme gücü özgürlük olarak algılansa da bu durumun izleme pratiğinde bir değişime yol açtığı savunulabilir. O halde katılımcı kendini özgürleşmiş olarak görse de içeriğe bir şekilde yine tüketmekte hatta geleneksel medyada tükettiğinden daha fazlasını tüketmektedir. Zira alınan cevaplar göstermektedir ki bireylerin dizinin yeni sezonu geldiğinde bölümlerin tamamını izleme eğilimi, tüketimin aşırılaşmasına neden olmakta; diğer günlerde diğer içeriklere yönelmesine ve onları tüketmesine teşvk etmektedir. Bu durumun Netflix'in pazarlama teknikleri ve kullandıkları arayüz aracılığıyla (dizinin bölümü bittikten sonra otomatik diğer bölüme geçişi) tüketiciyi ekrana bağlayan yapısı ile ilişkisi mevcuttur. Keza Netflix, 2013 yazında yaptığı bir araştırmada izleyicilerin yaklaşık \%10'unun tüm sezonu yirmi dört saat içinde tamamladığını açıklar (Wallenstein, 2013). Yurtdışındaki izleme pratiklerindeki değişimin Türkiye'ye yansıması özellikle 2019 sonrasında gerçekleşir. Televizyon izlemediğini söyleyen katılımcıların birçoğu, yeni sezon dizi içeriklerini arka arkaya izlediğini ve bir ya da birkaç gün içinde tüm sezonu bitirdiklerini belirtir.

Özellikle çoğu katılımcı karantina döneminde evde daha fazla vakit geçirdikleri için izleme pratiklerindeki artışı ifade ederler. İzleme pratiklerindeki niceliksel artışın yanı sıra katılımcılar ilgilerini çekmeyen içerikleri de tüketmeye başlayarak niteliksel olarak da artış göstermektedir. Pandeminin değiştirdiği gündelik hayat pratikleri izleme alışkanlıklarını doğrudan etkilemiş görünmektedir. Bu duruma istisna olan iki katılımcı bulunmaktadır. Öğretmen olan katılımcılar iş yüklerinin artışı nedeniyle diğer katılımcıların aksine daha az içerik tüketmektedir.

\section{SONUÇ}

Yapılan araştırmada kültürel sermayesi yüksek olan bireylerin gündelik yaşam pratiklerinde kültürel sermayesi düşük olan bireylerin televizyon izleme pratiğini motif değiştirerek yeni tür televizyon/yeni nesil izleme pratiği olarak değerlendirilebilecek olan dijital platforma kaydırdığı sonucuna ulaşılmıştır. Katılımcılar geleneksel medyadaki içeriği muhafazakarlaşma, benzer konu üretimi, gerçeklik sorunu ve yerelleşme bağlamlarında değerlendirirken aynı zamanda bu boş zaman etkinliğini aşağı bir eylem olarak konumlamaktadırlar. Ancak katılımcılar Netflix'teki izleme pratiklerini ve bu platformdaki içerikleri ise gündelik hayatla benzerlik ya da özdeşleşme boyutunda değerlendirmekte ve küresellik vurgusunun altını çizerek müdahale edilen özgürlük alanlarına yönelik alternatif bir yol olarak görmekte ek olarak batılı hayat tarzını sembolize eden tüketimler olarak belirtmektedirler. Bu sonuç bizi geleneksel medya içeriklerini kalitesiz ve aşağı olarak nitelendiren bireylerin aşağı bir konumda yer alamamak için tükettiği geleneksel medya içeriklerini reddettiği değerlendirmesine götürmektedir. Diğer taraftan kültürel semayeyi sosyal sermayeye dönüştürme sürecinde kitlesel üretime ve sosyal ilişki ağına vurgu yapan DiMaggio'nun çalışmasından hareketle bu araştırmada da katılımcıların sosyal aidiyet ve bir tür sosyal gruplara olan dolaylı bağlılık kurma ihtiyacı ve dışlanmaya maruz kalmama düşüncesi ile eşzamanlı tüketimler yaptığı sonucuna ulaşılmıştır. Kendi toplumsal sınıfında ekonomik koşullarının izin verdiği ölçüde hayatını şekillendiren bireyler, ekonomik olarak kaygan zeminde bulunmalarından dolayı geçmişe oranla daha az kültürel pratikleri deneyimlediklerini ancak alt sınıfsal gruplardan ayrışma sürecinde Netflix tüketimini kültürel bir içerik olarak değerlendirdikleri görülmektedir. Başka bir deyişle katılımcıların Netflix'i bir tür kişisel zenginleşme aracı olarak gördükleri bu noktada kendilerini alt sınıflardan ayırmak için geleneksel medya içeriklerini olumsuzladıkları söylenebilir. $\mathrm{Bu}$ verilere ek olarak araştırmada kendi bireysel tercihlerine yönelik içerik 
tüketiminde bulunan katılımcıların geleneksel medyadan daha fazla izleme pratiğini gerçekleştirdiği ve pandemi döneminde daha fazla boş vakite sahip olmalarından kaynaklı olarak sürekli izleme için tutarlı bir neden geliştirdikleri ve izleme eşiklerini yükselterek Muhdar'a atıfla "açık büfe" Netflix içeriklerini aşırı izleme motivasyonları ile tükettikleri belirtilebilir.

\section{KAYNAKÇA}

AAKER, J.L. (1999). "The malleable self: the role of self-expression in persuasion.” Journal of Marketing Research, 36, 43-57.

AKKUŞ, T. (2019). “Kan benim kanal benim.” TRT Akademi Dergisi, 4(7), 179-183. Erişim adresi: https://dergipark.org.tr/tr/download/article-file/638800

ANALECT (2014), Tune in: The Impact of Binge Viewing, https://www.slideshare.net/asmolick/annalect-primaryresearch- the-impact-of-bingeviewing-final-7-102014

ARSLAN, Z. (2012). “Geçmişten Bugüne Eleştirel Bir Orta Sınıf Değerlendirmesi.” Toplum ve Demokrasi Dergisi, 6(13), 55-92.

BALOĞLU, U. (2019). "Yaşam Biçimlerinin Televizyon Dizilerinde Yansıtılması: Bizimkiler Örneği.” MANAS Sosyal Araştırmalar Dergisi, 8(3), 2875-2897.

BAUDRILLARD, J. (2016). Tüketim Toplumu, İstanbul: Ayrıntı Yayınları.

BLAIR, T., BURRER, T., GARCIA, J., HERNANDEZ, A., LI-SOUTHWICK, Q. Y., LOGAR, K. \& PORTER, L. (2019). Netflıx Company Analysis (PDF Belgesi). http://tessacreates.com/wp-content/uploads/pdfs/Netflix-CompanyAnalysis.pdf.

BOCOCK, R. (2005). Tüketim. Dost Kitabevi.

BOURDIEU, P. (2014). Simgesel sermaye ve toplumsal sınıflar. Çev. Nazlı Ökten, Cogito, 76, 192-203.

BOURDIEU, P. (2015). Ayrım: Beğeni yargısının toplumsal eleştirisi. Heretik.

DiMAGGIO, P. (1987). Classification in art. American sociological review, 440-455.

EYCE, B. (1999). "Sosyal tabakalaşma tipolojisinde Weberiyan model.” Selçuk Üniversitesi Edebiyat Fakültesi Dergisi, (13), 271-287.

FLICHY, P. (1995). "Dynamics of modern communication: The shaping and impact of new communication technologies.” in J. Corner, P. Scannell, Garnham, P. Schelsinger, C. Sparks, \& Wood (Eds.), Media culture and society. London: Sage.

GARNHAM, N. (1993). Bourdieu, the cultural arbitrary, and television. Bourdieu: critical perspectives, 178-192.

HITCHCOCK, L. A. (2013). Kuramlar ve Kuramcılar, çev. Seda Pekşen, İstanbul: İletişim Yayınlar1.

JAWORSKI B. (2021). Netflix: Reinvention across mutiple time periods. AMS Review. https://link.springer.com/article/10.1007\%2Fs13162-021-00195-y. 
JENNER, M. (2018). Netflix \&The Re-Invention of Television. Cambrige UK: Palgrave Macmillan.

JENSEN, K. \& ROSENGREN, K. E. (2005). İzleyicinin Peşindeki Beş Gelenek (Ş. Yavuz ve Y. Yavuz, Ed.), Medya ve İzleyici Bitmeyen Tartışma, Ankara: Vadi.

KARADEMİR HAZIR, I. (2014). "Bourdieu sonrası yeni eşitsizlik gündemleri: Kültürel sınıf analizi, beğeni ve kimlik.” Cogito, 76, 230-264.

LIZARDO, O. (2006). "How cultural tastes shape personal networks.” American Sociological Review, 71(5), 778-807.

LÓPEZ-SINTAS, J., ROJAS DE FRANCISCO, L., \& GARCÍA-ÁLVAREZ, E. (2017). "Home-based digital leisure." World Leisure Journal, (59), 86-92.

MANLEY, L. (2013). “Post-Water-Cooler TV.” New York Times 11 Aug. AR1. Print.

MATRIX, S. (2014). "The Netflix effect: Teens, binge watching, and on-demand digital media trends.” Jeunesse: Young People, Texts, Cultures, 6(1), 119-138.

MICHAEL E. (1981). Sobel, Lifestyle and Social Structure: Concepts, Definitions, Analyses, New York: Academic Press Inc.

MORABITO, A. (2014). "Viewership for AMC's Walking Dead Soars.” New York Post. NYP Holdings, 15 Oct. 2013. Web. 14 June 2014.

MORRISON, M. \& KRUGMAN, D. (2001). "A look at mass and computer mediated technologies: Understanding the roles of television and computers in the home," Journal of Broadcasting \& Electronic Media, 45(1), 135-161.

NEWCOMB, H. (1994). Television: The critical view. Fifth edition. New York: Oxford University Press.

ÖZONUR, D. (2010). “Türkiye'de ‘yeni orta sınıf’ üzerine bir analiz: Issız Adam; ‘yuppie’ Alper”. Marmara İletişim Dergisi, 16, 187-200.

PALABIYIK, A. (2011). "Pierre Bourdieu Sosyolojisinde 'Habitus', 'Sermaye' ve 'Alan' Üzerine.” Liberal Düşünce Dergisi, (62), 1-21.

ROSS, G. (1978). "Marxism and the New Middle Classes: French Critiques", Theory \& Society, 5(2), s.163-190.

SARI, Ü. \& TÜRKER, H. (2021). "Dijital Platform Kullanıcılarının İzleme Alışkanlıklarına Yönelik Bir Araştırma: Netflix Örneği.” Anadolu Üniversitesi Sosyal Bilimler Dergisi, 21 (1), 59-80.

SINTAS, J. L., de FRANCISCO, L. R. \& ÁLVAREZ, E. G. (2015). "The Nature of Leisure Revisited.” Journal of Leisure Research, 47(1), 79-101.

SKEGGS, B. (1997). Formations of class \& gender: Becoming respectable. Sage.

SLATER, D. (1997). Consumer Culture and Modernity, Cambridge: Polity Press

SMITH, P. (2007). Kültürel kuram. Çev. Güzelsarı, S., \& Gündoğdu, İ. İstanbul: Babil Yayınları. 
SOBEL, M. E. (1981). Lifestyle and Social Structure: Concepts, Definitions, Analyses, Academic Press Inc. New York.

SPANGLER, T (2013). Netflix survey: Binge-watching is not weird or unusual. Available at: http://variety.com/2013/digital/news/netflix-survey-binge-watching-isnot-weird-orunu-sual-1200952292/

STEINER, E. \& XU, K. (2020). "Binge-watching motivates change: Uses and gratifications of streaming video viewers challenge traditional TV research." The International Journal of Research into New Media Technologies, 26 (1). 82-101. doi: $10.1177 / 135.485 .6517750365$.

SWEETMAN P. (2003). "Twenty-First Century Dis-Ease? Habitual Reflexivity Or the Reflexive Habitus". The Sociological Review. 51(4), 528-549

ŞAYLAN, G. (2002). Postmodernizm, Ankara: İmge Kitabevi

TICHI, (1991). Electronic hearth: Creating an American television culture. New York: Oxford University Press.

TOPÇU, U.C., EROĞLU, U. \& ÖZER, A. (2020). “Gösterişçi Tüketimin Kökenleri: Benlik, Sosyal Statü ve Tüketici Materyalizmi.” Tüketici ve Tüketim Araştırmaları Dergisi, 12(1), 151-185.

TRYON, C. (2015). “TV Got Better: Netflix’s Original Programming Strategies and Binge Viewing." Media Indisturies Journal. 2 (2).104-116. doi: https://doi.org/10.3998/mij.15031.809.0002.206

TURKLE, S. (2011). Alone together: Why we expect more from technology and less from each other. New York, NY: Basic books.

TURNER, J., BEEGHLEY, L. \& POWERS, C. H. (2010). Çev. Ümit Tatlıcan, Sosyolojik Teorinin Oluşumu. Ankara: Sentez Yayıncılık

TÜRDÜ, N. (2021). Webrazzi Insights Medya Tüketim Alışkanlı̆̆ (Araştırma Raporu). https://webrazzi.com/2021/02/04/medya-tuketim-aliskanligi-arastirma-raporu/

ULUÇ, G. (2008). Küreselleşen Medya: İktidar ve Mücadele Alanı. İstanbul: Kırmızı Yayınları.

ÜSTÜNER, T. \& HOLT, D. (2010), "Toward a Theory of Status Consumption in Less Industrialized Countries", Journal of Consumer Research, 37 (1), s. 37-56.

VIÑALS-BLANCO, A. (2015). The transformation of leisure in the digital age. In B. Çoban (Ed.), Social media and social movements: The transformation of communication patterns (pp. 165-180). Lanhan, MD: Lexington Books.

VIRILIO, P. (1995). "Speed and information: cyberspace alarm!.” Ctheory, 18(3), 1-5.

WALLENSTEIN, A. ““Arrested Development' Draws Big Early Netflix Audience.” Variety. Variety Media, 28 May 2013. Web. 14 June 2014.

WEBER, M. (2012). Ekonomi ve Toplum. Çev. Latif Boyacı, İstanbul: Yarın Yayınları.

WYNNE, D. (2002). Leisure, lifestyle and the new middle class: A case study. Rout 